

Thermal Analyses of $\mathrm{SRS} P \mathrm{P}$ Storage Cans Inside BNFL 3013 Contaner 


\section{DISCLAIMER}

This report was prepared as an account of work sponsored by an agency of the United States Government. Neither the United States Government nor any agency thereof, nor any of their employees, make any warranty, express or implied, or assumes any legal liability or responsibility for the accuracy, completeness, or usefulness of any information, apparatus, product, or process disclosed, or represents that its use would not infringe privately owned rights. Reference herein to any specific commercial product, process, or service by trade name, trademark, manufacturer, or otherwise does not necessarily constitute or imply its endorsement, recommendation, or favoring by the United States Government or any agency thereof. The views and opinions of authors expressed herein do not necessarily state or reflect those of the United States Government or any agency thereof. 


\section{DISCLAIMER}

Portions of this document may be illegible in electronic image products. Images are produced from the best available original document. 


\section{Thermal Analyses of SRS Pu Storage Cans Inside BNFL 3013}

\section{Container}

by

P. K. Paul

Westinghouse Savannah River Company

Savannah River Site

Aiken, South Carolina 29808

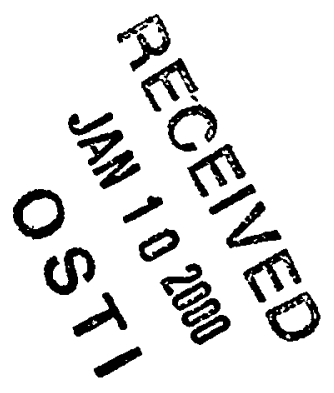

DOE Contract No. DE-AC09-96SR18500

This paper was prepared in connection with work done under the above contract number with the U.S.

Department of Energy. By acceptance of this paper, the publisher and/or recipient acknowledges the U.S.

Government's right to retain a nonexclusive, royalty-free license in and to any copyright covering this paper, along with the right to reproduce and to authorize others to reproduce all or part of the copyrighted paper. 
KEYWORDS: Thermal Analyses Plutonium

Storage

BNFL 3013

FB-Line

\title{
Thermal Analyses of SRS Pu Storage Cans Inside BNFL 3013 Container
}

\author{
By \\ P. K. Paul \\ ISSUED: October 1999
}

SRTC Savannah River Technology Center, Aiken, SC 29808 Westinghouse Savannah River Company

Prepared for the U.S. Department of Energy under Contract DE-AC09-96SR185000 
WSRC-TR-98-00462

Rev 0

DOCUMENT: $\quad$ WSRC-TR-98-00462

TITLE: Thermal Analyses of SRS Pu Storage Cans Inside BNFL 3013 Container

APPROVALS

Rrankfanl

Date: $10 / 6 / 99$

P. K. Paul, Author

SRTC/EESD/EDS, Engineering Modeling \& Simulation Group

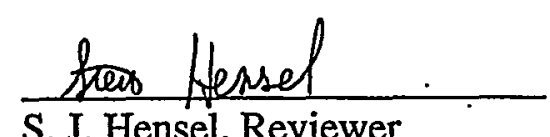

Date: $10 / 8 / 99$

SRTC/EESD/EDS, Engineering Modeling \& Simulation Group

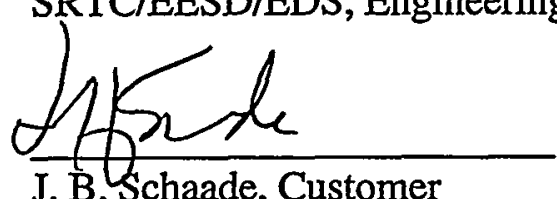

J. B. Shade, Customer NMSS Engineering

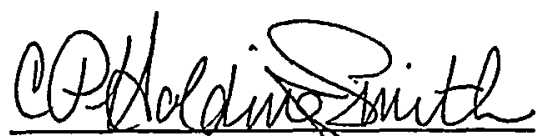

C. P. Holding-Smith Group Manager

SRTC/EESD/EDS, Engineering Modeling \& Simulation Group

$\frac{m \cdot \text { a. EP ra }}{\text { M.A. Bra, Section Manager }}$

SRTC/EESD/EDS
Date: $10-12-99$

Date: $10 / 19 / 99$

iv 


\section{Table of Contents}

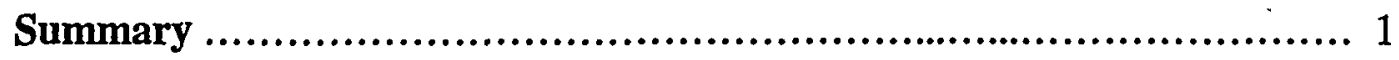

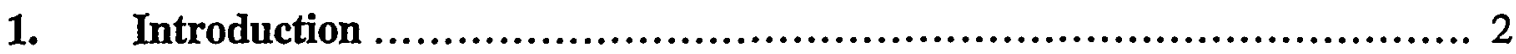

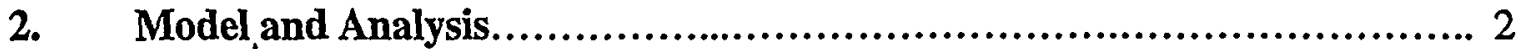

2.1 Model ................................................................ 6

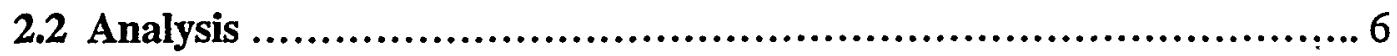

3. Results \& Discussions........................................................

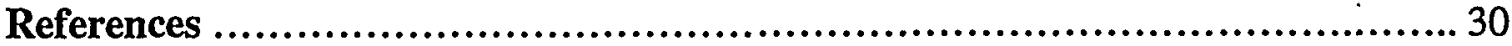


Figures

1. A Schematic of Single SRS Can Containing a Pu Ingot on a

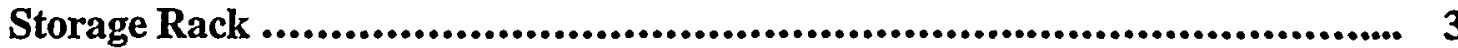

2. A Schematic of Two-Stacked SRS Can Sitting on a Storage Rack ................................................................................ 4

3. A Schematic of Two-Stacked SRS Can Hanging in the Ambient ............................................................................ 5

4. Materials Display in Single Can Configuration ..................................... 7

5. Materials Display in Two-Stacked Can Configuration Sitting on a Rack .........................................................................8 8

6. Materials Display in Two-Stacked Can Configuration Hanging in the Ambient .......................................................... 9

7. Node Location for Single Can Configuration ........................................... 14

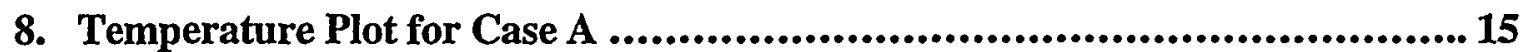
(7.0 watts heat source and He enclosure medium)

9. Temperature Plot for Case B 16 (10.5 watts heat source and He enclosure medium)

10. Temperature Plot for Case $C$ 17 (10.5 watts heat source and air enclosure medium)

11. Temperature Plot for Case $D$ 18 (10.5 watts heat source and $25 \%$ air $+75 \%$ He enclosure medium)

12. Temperature Plot for Case $\mathrm{E}$ (10.5 watts heat source and $50 \%$ air $+50 \%$ He enclosure medium)

13. Temperature Plot for Case $F$ 20 (10.5 watts heat source and 50\% air $+50 \%$ He enclosure medium and convection effects within enclosure medium)

14. Node Locations for Two-Stack Can Configuration 22

15. Temperature Plot for Case AA 23 (outer enclosure medium air and configuration sitting on a rack) 
16. Temperature Plot for Case BB

(outer enclosure medium nitrogen and configuration sitting on a rack)

17. Temperature Plot for Case CC

(outer enclosure medium helium and configuration sitting on a rack)

18. Temperature Plot for Case AAA (outer enclosure medium air and configuration hanging in ambient)

19. Temperature Plot for Case BBB

(outer enclosure medium nitrogen and configuration hanging in ambient)

20. Temperature Plot for Case CCC

(outer enclosure medium helium and configuration hanging in ambient)

21. Temperature Plot for Case DDD .29

(outer enclosure medium nitrogen and configuration hanging in ambient and bottom insulated boundary)

\section{Tables}

1. External Dimensions of Containers

2. Material Properties Used in the Analyses .......................................... 10

3. Listing of Cases Analyzed ........................................................... 11

4. Temperature at Different Locations for Single Can Configuration ............... 13

5. Temperature at Different Locations for Two-Stacked Can Configuration ..... 21 


\section{Summary}

Thermal analyses of plutonium ingot storage in the single SRS can and the two-stacked SRS cans (each containing a Pu ingot) inside a BNFL 3013 outer can configuration have been performed. The stacked can configuration is analyzed for two different variations. In one situation the stacked cans are sitting on a rack and in another situation the stacked cans are hanging freely in the ambient. Sensitivity analyses have been performed by using helium, air or a combination of helium and air as the enclosure medium between the $\mathrm{Pu}$ ingot and the SRS can. Sensitivity analyses also include choosing helium, air, nitrogen or a combination of air and helium as the enclosure medium between the inner SRS can and the outer BNFL can. In all analyses, the ambient temperature is assumed to be $95^{\circ} \mathrm{F}$. The heat source in the $\mathrm{Pu}$ ingot is used as 10.5 watts for all cases except one that has 7.0 watts.

The highest temperature calculated is on the top of the $\mathrm{Pu}$ ingot at the centerline location for the single can configuration. The highest temperature for the single can configuration base case (10.5 watts heat source $\mathrm{Pu}$ button; $25 \%$ air and $75 \% \mathrm{He}$ as the enclosure medium between the $\mathrm{Pu}$ ingot and the can; no convection inside the enclosure) is $184^{\circ} \mathrm{F}$. The highest temperature increases to $197^{\circ} \mathrm{F}$ as the enclosure medium becomes $100 \%$ air. The highest temperature drops to $171^{\circ} \mathrm{F}$ if convection heat transfer in addition to conduction heat transfer is included inside the enclosure medium which is $50 \%$ air and $50 \%$ helium. The base case highest temperature drops to $155^{\circ} \mathrm{F}$ if the heat source of the $\mathrm{Pu}$ ingot drops to 7.0 watts from 10.5 watts. The base case temperature on the outside top of the can is approximately $118^{\circ} \mathrm{F}$.

For the two-stacked cans configuration sitting on a rack (10.5 watts heat source $\mathrm{Pu}$ ingot; enclosures between Pu button and SRS can filled with $25 \%$ air $+75 \% \mathrm{He}$; enclosures between SRS cans and outer can filled with air; no convection assumed inside the enclosures), the highest temperature is $181^{\circ} \mathrm{F}$ at the top of the upper $\mathrm{Pu}$ ingot in the centerline location. But when the two-stacked cans are hanging, the highest temperature increases to $185^{\circ} \mathrm{F}$ and this temperature is at the top of the lower $\mathrm{Pu}$ ingot. The temperatures at the top of the outer can for the two-stacked cans configuration is around $120^{\circ} \mathrm{F}$. 


\subsection{Introduction}

Plutonium metal is stored at the Savannah River Site (SRS) using different storage can configurations. The temperatures at different locations in the storage configuration play an important role in designing and configuring different storage arrangements. The present work consists of calculating temperatures at different locations in two different storage configurations. The configurations are: 1) storing $\mathrm{Pu}$ ingot in a single SRS storage can (Bagless Transfer Can) and 2) storing two Pu ingots in two stacked SRS cans (Bagless Transfer Cans) inside a BNFL 3013 outer can. The external dimensions of the SRS can and the BNFL 3013 outer can are given in Table 1. The schematics of the 2-D axisymmetric quarter plane along with necessary dimensions for the two configurations are presented in Figures 1,2 and 3. The heat source in each $\mathrm{Pu}$ ingot is assumed to be 10.5 watts (with the exception of one case which is 7.0 watts), and the ambient temperature used for the analyses is $95^{\circ} \mathrm{F}$.

The work has been performed in accordance with the WSRC E-7 Manual ${ }^{1}$. The thermal analyses have been performed using a finite element based commercial code which meets site nuclear $\mathrm{QA}$ requirements ${ }^{2}$.

\section{Table 1. External Dimensions of Containers}

\begin{tabular}{|l|l|l|}
\hline Container & $\begin{array}{c}\text { Diameter X Height } \\
\text { (inch) }\end{array}$ & Drawing Number \\
\hline SRS Can & $4.6 \times 4.625$ & $\begin{array}{l}\text { WSRC Drawing } \\
\text { R-R1-F-0039 Rev. 2 }\end{array}$ \\
\hline $\begin{array}{l}\text { BNFL 3013 Outer } \\
\text { Container }\end{array}$ & $4.92 \times 10.0$ & $\begin{array}{l}\text { BNFL Drawing } \\
\text { M-4-20-1-245 Mod C }\end{array}$ \\
\hline
\end{tabular}

\subsection{Model and Analysis}

The thermal models of the Pu storage configurations have been created using the general purpose finite element pre- and post-processor MSC/PATRAN ${ }^{3}$ Version 7.5.- The analyses have been performed using the general purpose conduction-radiation based finite element code $\mathrm{MSC} /$ Thermal $^{4}$ (P/Thermal). 


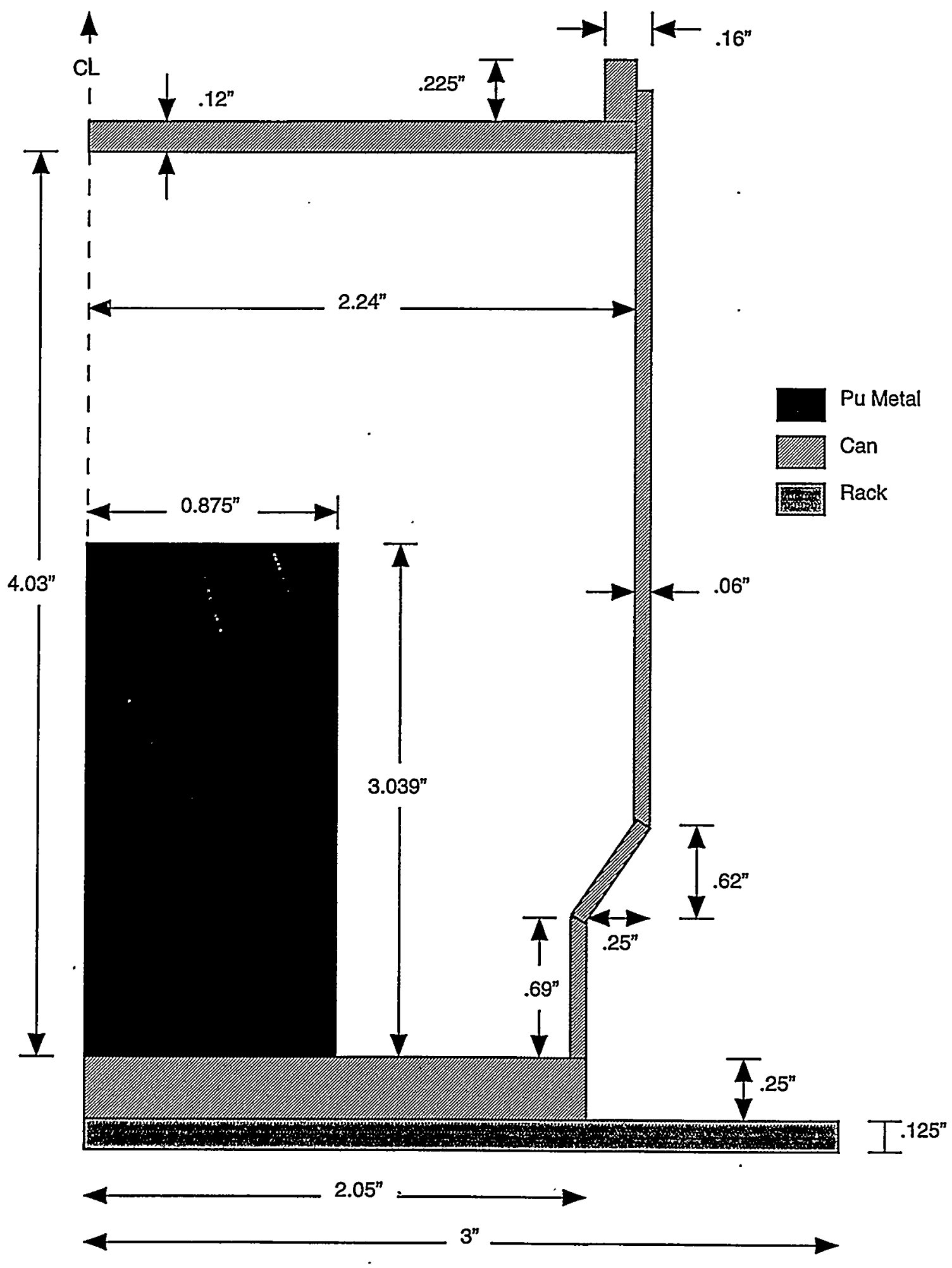

Figure 1. A Schematic of Single SRS Can Containing a Pu Ingot on a Storage Rack 


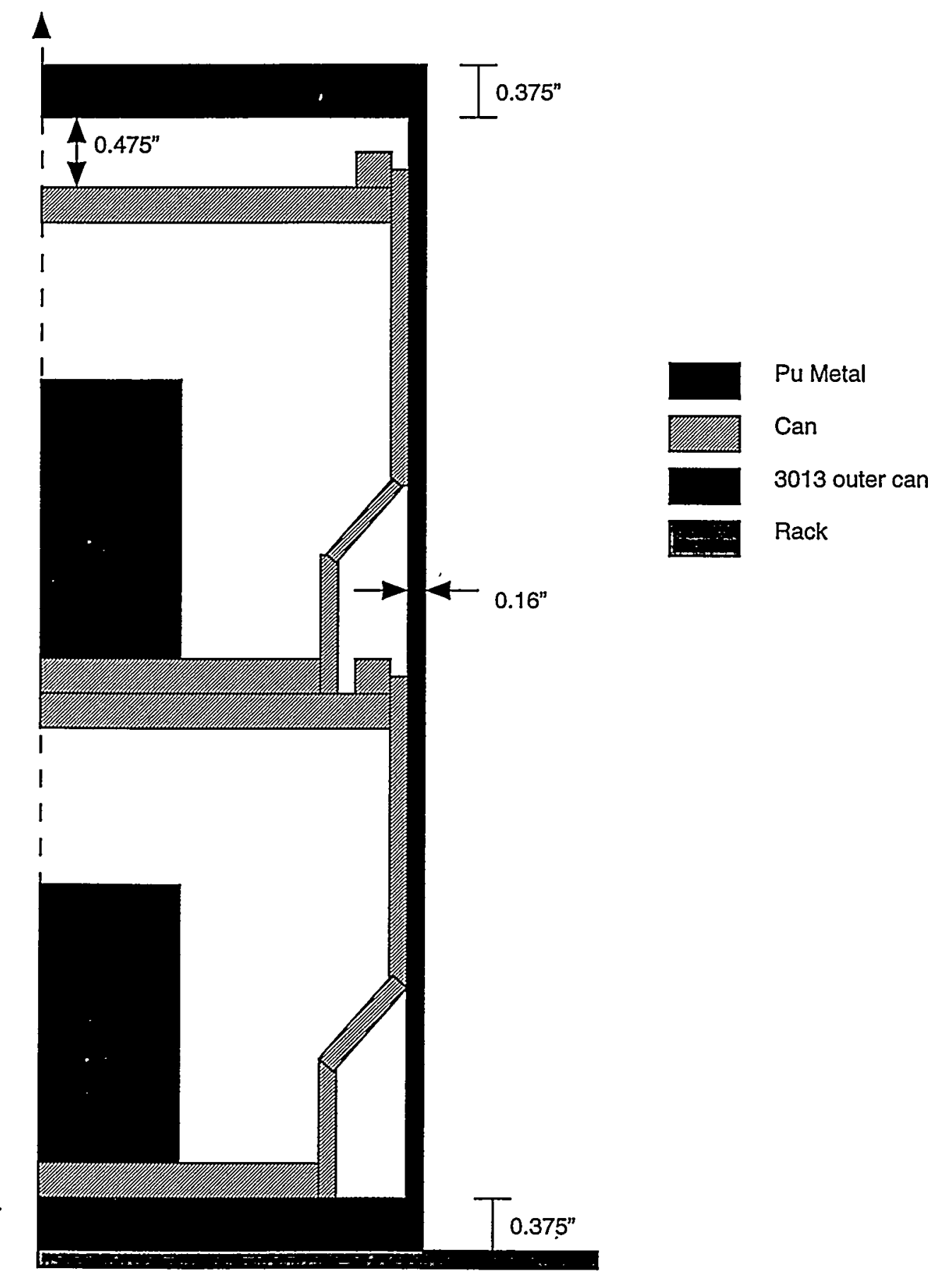

Figure 2. A Schematic of Two-Stacked SRS Can Sitting on a Storage Rack 

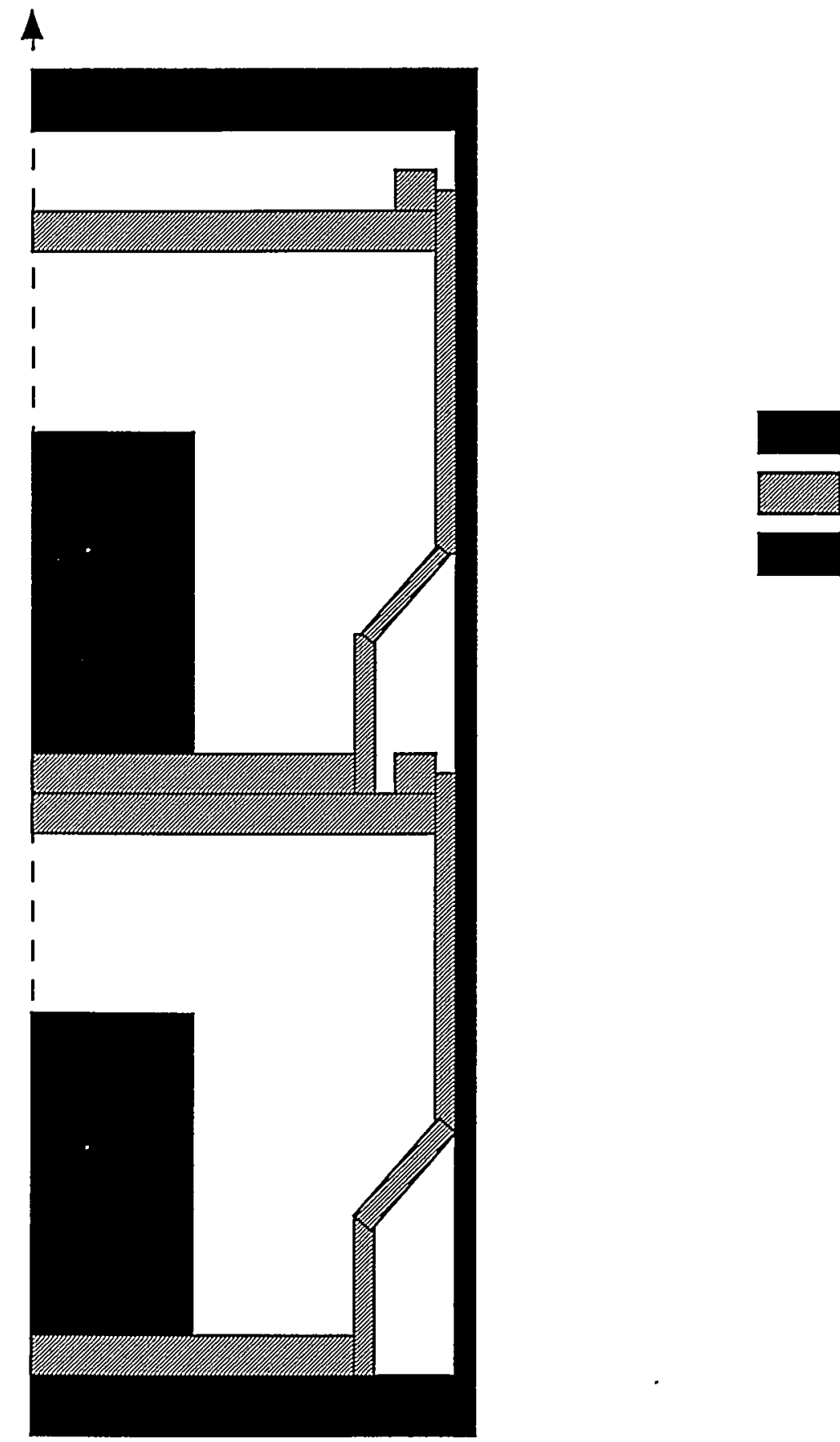

Pu Metal

Can

3013 outer can

Figure 3. An Schematic of Two-Stacked SRS Can Hanging in the Ambient 


\subsection{Model}

The single SRS storage can containing a $\mathrm{Pu}$ ingot is modeled by a 2-D axisymmetric quarter plane. Figure 1 shows this quarter plane model with its dimensions. The 2-D axisymmetric model for the two stacked SRS storage cans (with a Pu ingot in each can) within the BNFL 3013 outer can is shown in Figure 2. In Figure 2, the two-stacked can configuration is sitting on a 304 stainless steel rack, whereas in Figure 3 the configuration is hanging in a free space. The quarter planes are modeled using 1300 nodes for the single can and 3000 nodes for the two-stacked can configurations. The fringe plot in Figures 4,5 , and 6 shows the materials for these configurations. The SRS can is made of 304 stainless steel and the BNFL outer can is made of 316 stainless steel.

A volumetric heat source of 10.5 watts is uniformly distributed over in each $1.75^{\text {" }}$ diameter $\mathrm{Pu}$ ingot of 2300 grams. In one case, a volumetric heat source of 7.0 watts is used for sensitivity analysis. The ambient temperature is modeled as $95^{\circ} \mathrm{F}$.

The heat dissipation is modeled as conduction heat transfer through the structural components of the storage configurations. Radiation heat transfer is modeled between the Pu ingot and the SRS can, between the inner can and the outer can (for Fig 2 and 3 configurations only), and from the outer surfaces to the ambient. An emissivity of value 0.3 is used for all surfaces, which may be considered conservative. Higher emissivity values would result in lower the temperatures. Laminar natural convection $(h=0.363 \Delta T$ $0.25 \mathrm{Btu} / \mathrm{hr}-\mathrm{ft}^{2}-\mathrm{F}$ ) from the side of the outer can to the ambient and turbulent natural convection $\left(\mathrm{h}=0.22 \Delta \mathrm{T}{ }^{0.33} \mathrm{Btu} / \mathrm{hr}-\mathrm{ft}^{2}-{ }^{\circ} \mathrm{F}\right)$ off the top of the outer can are used as boundary conditions. A turbulent natural convection $\left(\mathrm{h}=0.22 \Delta \mathrm{T}^{0.33} \mathrm{Btu} / \mathrm{hr}-\mathrm{ft}^{2}-{ }^{\circ} \mathrm{F}\right)$ is also applied to the to exposed part of the rack for the seating on a rack configuration and to the bottom part of the outer can for the hanging configuration. The convective heat transfer between the $\mathrm{Pu}$ ingot and the SRS can and between the inner can and the outer can is neglected in all cases but three (Cases F, G \& H). In that case, the convective effects are implemented by adjusting the conductivity of the fill gas with a multiplication factor of 2.6 radially and 8.0 axially ${ }^{5}$.

\subsection{Analysis}

The general purpose conduction/radiation code MSC/Thermal Version 5.0 is used to perform the computations. The finite element mesh generation and pre- and postprocessors are done using MSC/PATRAN Version 7.5. The quarter plane 2-D axisymetric models contain about 1300 and 3000 nodes for the single can and double stacked can configurations, respectively. The material properties used for 304 stainless steel, helium, nitrogen, and air are from the MSC/Thermal material property package. Table 2 shows the material properties used in the analyses. The cases analyzed under three different configurations are presented in Table 3. 


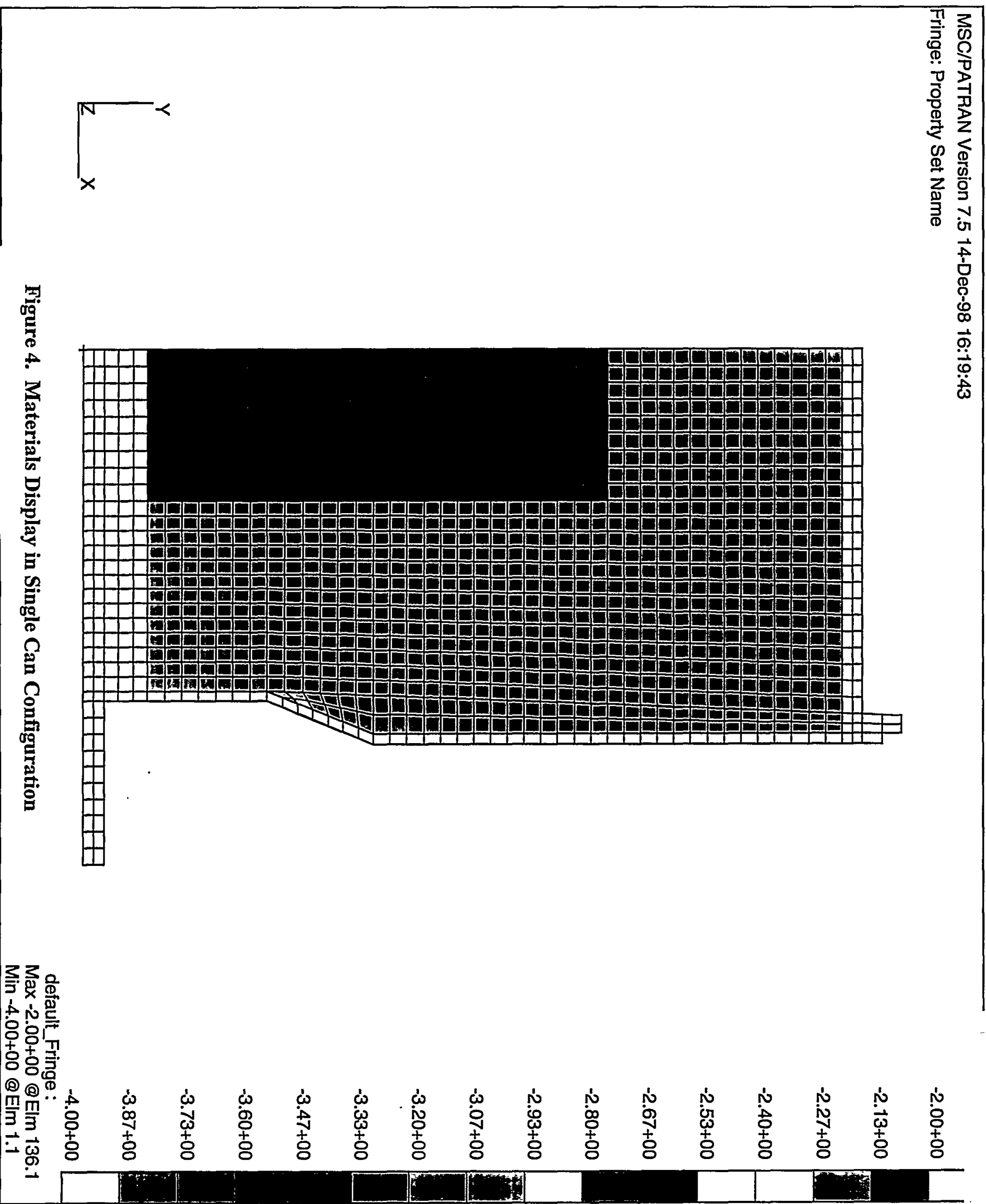



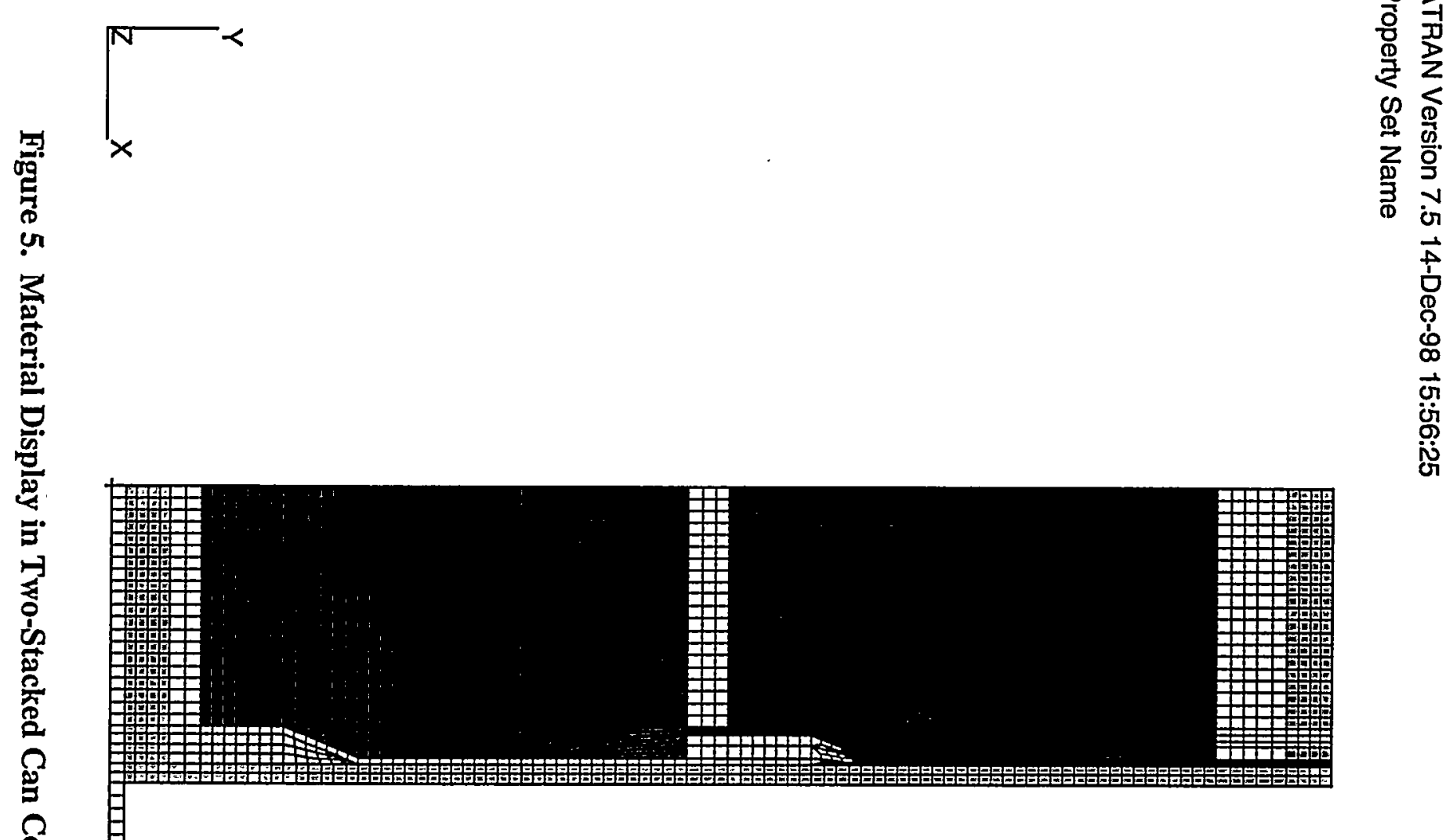

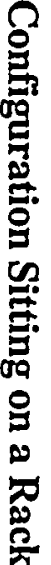

족웅

ơ $\dot{1}$

ㅇㅇㅇ항

ㅇㅇㅇ형글

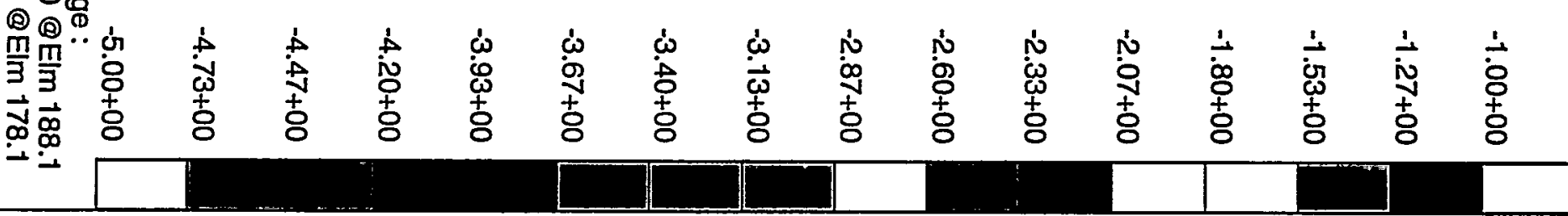




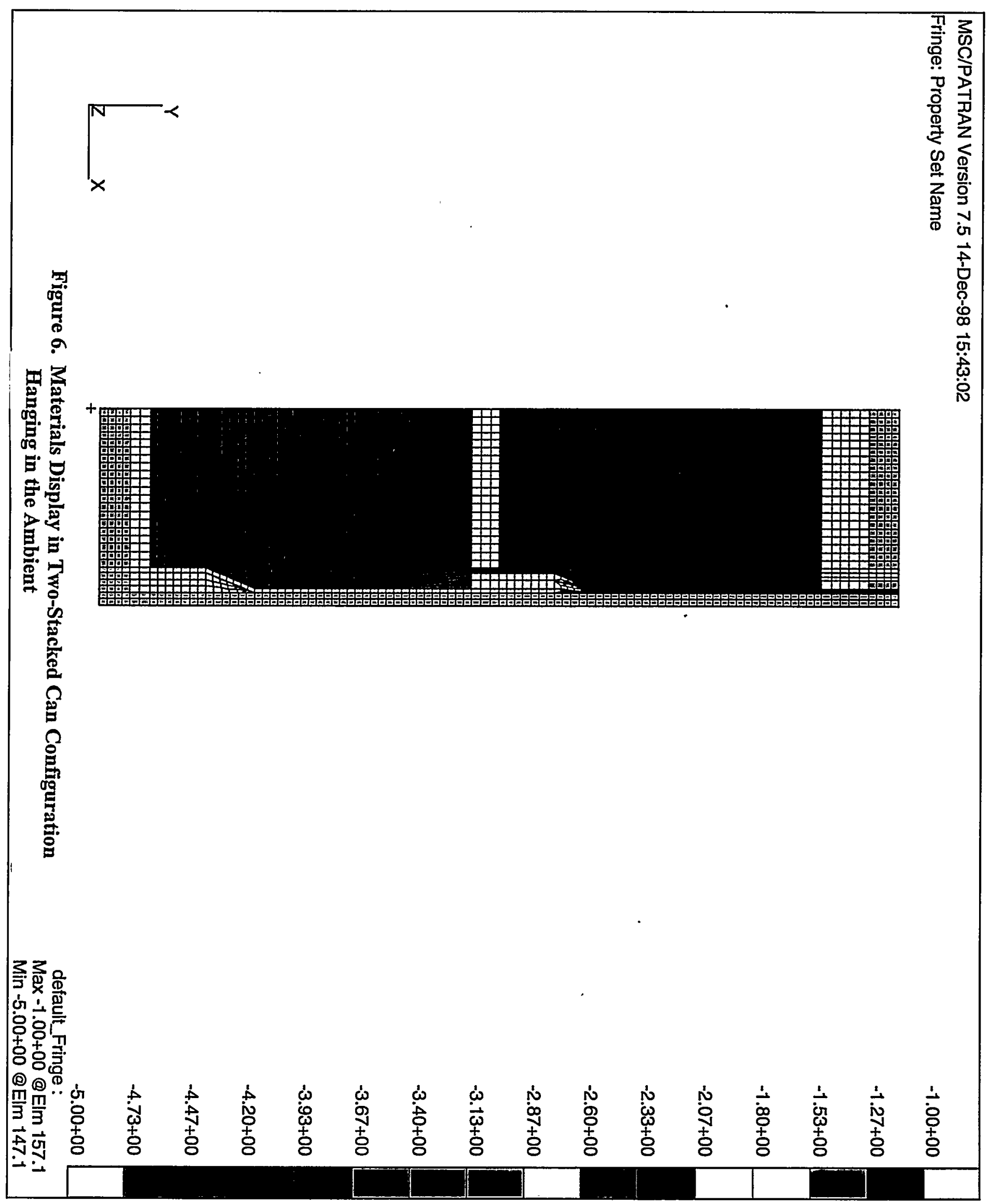


WSRC-TR-98-00462

Rev 0

Table 2: Material Properties used in the Analyses

\begin{tabular}{|c|c|c|c|}
\hline Material & $\begin{array}{l}\text { Density } \\
\left(\mathrm{lb} / \mathrm{ft}^{3}\right)\end{array}$ & $\begin{array}{l}\text { Specific Heat } \\
\left(\mathrm{Btu} / \mathrm{lb} \mathrm{b}^{\circ} \mathrm{F}\right)\end{array}$ & $\begin{array}{l}\text { Thermal Conductivity } \\
\left(\mathrm{Btu} / \mathrm{hr}-\mathrm{ft}-{ }^{\circ} \mathrm{F}\right)\end{array}$ \\
\hline $\begin{array}{c}\text { Stainless Steel } \\
304\end{array}$ & 494.4 & $\begin{array}{c}0.120 @ 32^{\circ} \mathrm{F} \\
0.135 @ 752^{\circ} \mathrm{F}\end{array}$ & $\begin{array}{c}7.74 @ 32^{\circ} \mathrm{F} \\
9.43 @ 212^{\circ} \mathrm{F}\end{array}$ \\
\hline $\begin{array}{l}\text { Stainless Steel } \\
\quad 316\end{array}$ & 494.4 & $\begin{array}{c}0.120 @ 32^{\circ} \mathrm{F} \\
0.135 @ 752^{\circ} \mathrm{F}\end{array}$ & $\begin{array}{c}7.61 @ 32^{\circ} \mathrm{F} \\
8.79 @ 212^{\circ} \mathrm{F}\end{array}$ \\
\hline Plutonium & 1198.6 & $\begin{array}{c}0.032 @ 32^{\circ} \mathrm{F} \\
0.0328 @ 212^{\circ} \mathrm{F}\end{array}$ & $\begin{array}{c}4.596 @ 63^{\circ} \mathrm{F} \\
5.806 @ 135^{\circ} \mathrm{F} \\
7.257 @ 207^{\circ} \mathrm{F}\end{array}$ \\
\hline Nitrogen & 0.0781 & 0.245 & $\begin{array}{c}0.01389 @ 32^{\circ} \mathrm{F} \\
0.01807 @ 212^{\circ} \mathrm{F}\end{array}$ \\
\hline Helium & 0.0115 & 1.24 & $\begin{array}{c}0.0818 @ 32^{\circ} \mathrm{F} \\
0.0868 @ 77^{\circ} \mathrm{F} \\
0.0909 @ 120^{\circ} \mathrm{F} \\
0.0984 @ 212^{\circ} \mathrm{F}\end{array}$ \\
\hline Air & 0.0805 & 0.237 & $\begin{array}{c}0.0139 @ 32^{\circ} \mathrm{F} \\
0.0184 @ 212^{\circ} \mathrm{F}\end{array}$ \\
\hline $\begin{array}{c}25 \% \text { Air }+75 \% \\
\text { Helium }\end{array}$ & 0.0284 & 0.989 & $\begin{array}{c}0.0648 @ 32^{\circ} \mathrm{F} \\
0.0784 @ 212^{\circ} \mathrm{F}\end{array}$ \\
\hline $\begin{array}{c}50 \% \text { Air }+50 \% \\
\text { Helium }\end{array}$ & 0.0460 & 0.7385 & $\begin{array}{l}0.03935 @ 32^{\circ} \mathrm{F} \\
0.0484 @ 212^{\circ} \mathrm{F}\end{array}$ \\
\hline
\end{tabular}


Table 3. Listing of Cases Analyzed

\begin{tabular}{|c|c|c|}
\hline Configuration & Case & Description \\
\hline Single SRS Can & A & $\begin{array}{l}7.0 \text { watts heat source Pu button; enclosure between } \\
\text { Pu button and can filled with He; no convection } \\
\text { inside the enclosure (He medium) }\end{array}$ \\
\hline Single SRS Can & B & Same as Case A except 10.5 watts heat source \\
\hline Single SRS Can & C & Same as Case B except medium filled with air \\
\hline Single SRS Can & $\mathrm{D}$ & $\begin{array}{l}\text { Same as Case B except medium filled with } 25 \% \text { air } \\
+75 \% \mathrm{He} \text { (Base Case) }\end{array}$ \\
\hline Single SRS Can & $\mathrm{E}$ & $\begin{array}{l}\text { Same as Case B except medium filled with } 50 \% \text { air } \\
+50 \% \mathrm{He}\end{array}$ \\
\hline Single SRS Can & $\mathrm{F}$ & $\begin{array}{l}\text { Same as Case E except convection inside enclosure } \\
\text { is included. }\end{array}$ \\
\hline Single SRS Can & G & $\begin{array}{l}\text { Same as Case D except convection inside enclosure } \\
\text { is included }\end{array}$ \\
\hline Single SRS Can & $\mathrm{H}$ & $\begin{array}{l}\text { Same as A except medium filled with } 25 \% \text { air }+ \\
75 \% \text { He and convection inside enclosure included }\end{array}$ \\
\hline Double SRS cans sitting on a rack & AA & $\begin{array}{l}10.5 \text { watts heat Pu button in each enclosure; } \\
\text { enclosures between Pu button and SRS can filled } \\
\text { with } 25 \% \text { air }+75 \% \text { He; enclosure between SRS } \\
\text { cans and outer can filled with air; no convection } \\
\text { inside the enclosures }\end{array}$ \\
\hline Double SRS cans sitting on a rack & BB & $\begin{array}{l}\text { Same as Case AA except enclosure between SRS } \\
\text { cans and outer can filled with nitrogen }\end{array}$ \\
\hline Double SRS cans sitting on a rack & $\mathrm{CC}$ & $\begin{array}{l}\text { Same as Case AA except enclosure between SRS } \\
\text { cans and outer can filled with helium }\end{array}$ \\
\hline Double SRS cans hanging in air & AAA & $\begin{array}{l}10.5 \text { watts heat Pu button in each enclosure; } \\
\text { enclosures between Pu button and SRS can filled } \\
\text { with } 25 \% \text { air }+75 \% \text { He; enclosure between SRS } \\
\text { cans and outer can filled with air; no convection } \\
\text { inside the enclosures }\end{array}$ \\
\hline Double SRS cans hanging in air & BBB & $\begin{array}{l}\text { Same as Case AAA except enclosure between SRS } \\
\text { cans and outer can filled with nitrogen }\end{array}$ \\
\hline Double SRS cans hanging in air & $\mathrm{CCC}$ & $\begin{array}{l}\text { Same as Case AAA except enclosure between SRS } \\
\text { cans and outer can filled with helium }\end{array}$ \\
\hline Double SRS cans hanging in air & DDD & $\begin{array}{l}\text { Same as Case BBB except insulated boundary at } \\
\text { the bottom }\end{array}$ \\
\hline
\end{tabular}




\section{Results and Discussions}

The temperatures at different node locations for the single can configuration (Case A through $\mathrm{H}$ ) are presented in Table 4, and the locations of the nodes are shown in Figure 7. A brief description of the cases is provided in Table 3. The highest temperature calculated is at the center on the top of Pu button (node \# 631) for all cases. The highest temperature calculated for the Base Case (Case D) is $184^{\circ} \mathrm{F}$. The temperature at the top of the can is about $119^{\circ} \mathrm{F}$ for this case. The centerline temperature in the $\mathrm{Pu}$ ingot decreases from top to bottom. The high thermal conductivity of stainless steel on the can bottom facilitates heat loss through the bottom of the ingot. The temperature of $\mathrm{Pu}$ ingot decreases from top to bottom. The enclosure filled with gases of higher thermal conductivity enhances heat transfer from the Pu button to the stainless steel at the top of the can. As a result, the centerline temperature at the top of the can (node \#1239) increases as the composition of the enclosure increases from air to helium. No credit for internal convection within the enclosure inside the can has been taken except Cases F, G and $\mathrm{H}$. In Case $\mathrm{F}$, the internal convection is implemented by increasing the conductivity of the enclosure medium. As a result, the centerline temperature at the top of the $\mathrm{Pu}$ button is $19^{\circ} \mathrm{F}$ lower in Case $\mathrm{F}$ than that in Case $\mathrm{E}$. On the other hand, the centerline temperature at the top of the can is $11.5^{\circ} \mathrm{F}$ higher in Case $\mathrm{F}$ than that in Case E. The temperatures in Case $G$ is derived from Case $D$ by applying the enclosure medium convection effect based on Cases $\mathrm{E}$ and $\mathrm{F}$. In deriving the temperatures in Case $\mathrm{H}$, the effect of $25 \%$ air instead of helium based on Cases D and $E$ is incorporated into Case A in addition to the enclosure medium convection effect based on Cases $\mathrm{E}$ and $\mathrm{F}$. The temperature contour plots for Cases A though $\mathrm{F}$ are presented in Figures 8 though 13.

The temperatures for two-stacked can configuration cases are presented Table 5. The Cases AA, BB and CC are for stacked cans sitting on a rack, and in Cases AAA, BBB, $\mathrm{CCC}$ and $\mathrm{DDD}$, the stacked cans are hanging free. The node locations are shown in Figure 14. The calculated highest temperature for the base case (Case AA) is $181^{\circ} \mathrm{F}$ at the top of upper $\mathrm{Pu}$ ingot on the centerline location. The temperature at the top of the outer can is about $120^{\circ} \mathrm{F}$ for this case. The temperature differences among Cases AA and $\mathrm{BB}$ are insignificant because the conductivity of nitrogen is almost the same as that of air. The same explanation is applicable for AAA and BBB. The temperatures along the centerline are higher in the hanging configuration than those in the seating configuration. The temperature differential for the cases with and without the rack is the greatest at the can bottom, and generally decreases from bottom to the top. The configuration with the rack results in overall lower temperatures because of the increased surface area for heat transfer to the ambient. The temperature contours for case $\mathrm{AA}, \mathrm{BB}, \mathrm{CC}, \mathrm{AAA}, \mathrm{BBB}$, CCC, and DDD are presented in Figures 15 through 18. 
Table 4. Temperature at Different Locations for Single Can Configuration

\begin{tabular}{|c|c|c|c|c|c|c|c|c|}
\hline Case & Case A & Case B & Case C & Case D & Case E & Case F & Case $\mathbf{G}^{*}$ & Case H $^{*}$ \\
\hline Node \# & $\begin{array}{c}\text { Temp } \\
{ }^{\circ} \mathrm{F}\end{array}$ & $\begin{array}{c}\text { Temp } \\
{ }^{\circ} \mathrm{F}\end{array}$ & $\begin{array}{c}\text { Temp } \\
{ }^{\circ} \mathrm{F}\end{array}$ & $\begin{array}{c}\text { Temp } \\
{ }^{\circ} \mathrm{F}\end{array}$ & $\begin{array}{c}\text { Temp } \\
{ }^{\circ} \mathrm{F}\end{array}$ & $\begin{array}{c}\text { Temp } \\
{ }^{\circ} \mathrm{F}\end{array}$ & $\begin{array}{c}\text { Temp } \\
{ }^{\circ} \mathrm{F}\end{array}$ & $\begin{array}{c}\text { Temp } \\
{ }^{\circ} \mathrm{F}\end{array}$ \\
\hline 123 & 143.4 & 164.1 & 174.0 & 166.1 & 169.6 & 158.0 & 154.7 & 136.4 \\
\hline 235 & 149.0 & 172.0 & 183.9 & 174.4 & 178.7 & 164.8 & 160.8 & 140.8 \\
\hline 393 & 152.8 & 177.3 & 191.1 & 180.1 & 185.0 & 169.1 & 164.6 & 143.5 \\
\hline 631 & 155.2 & 180.6 & 196.8 & 183.9 & 189.7 & 170.5 & 165.3 & 143.9 \\
\hline 132 & 140.4 & 159.8 & 168.7 & 161.6 & 164.8 & 154.2 & 151.2 & 134.0 \\
\hline 244 & 148.7 & 171.4 & 183.5 & 173.9 & 178.2 & 164.3 & 160.3 & 140.5 \\
\hline 402 & 152.5 & 176.8 & 190.9 & 179.7 & 184.7 & 168.6 & 164.0 & 143.1 \\
\hline 640 & 154.3 & 179.4 & 196.4 & 182.9 & 188.9 & 168.8 & 163.4 & 142.4 \\
\hline 995 & 113.1 & 119.9 & 114.7 & 118.9 & 117.1 & 128.6 & 130.6 & 122.3 \\
\hline 1239 & 113.0 & 119.9 & 114.7 & 118.8 & 117.0 & 128.5 & 130.5 & 122.2 \\
\hline 1248 & 112.8 & 119.6 & 114.7 & 118.6 & 117.0 & 127.3 & 129.0 & 121.1 \\
\hline 1285 & 112.4 & 118.9 & 114.8 & 118.1 & 116.7 & 123.7 & 125.2 & 117.7 \\
\hline 1287 & 112.4 & 118.9 & 114.7 & 118.1 & 116.6 & 123.7 & 125.3 & 117.7 \\
\hline 1283 & 112.4 & 118.9 & 114.8 & 118.1 & 116.6 & 123.7 & 125.3 & 117.7 \\
\hline 1274 & 112.4 & 119.0 & 114.8 & 118.2 & 116.7 & 123.9 & 125.5 & 117.8 \\
\hline 1280 & 112.4 & 119.0 & 114.8 & 118.2 & 116.7 & 123.8 & 125.4 & 117.7 \\
\hline 1004 & 112.9 & 119.6 & 114.7 & 118.6 & 116.9 & 127.4 & 129.3 & 117.8 \\
\hline 1228 & 112.5 & 119.1 & 115.0 & 118.3 & 116.8 & 123.7 & 125.3 & 117.6 \\
\hline 72 & 132.9 & 148.6 & 154.8 & 150.0 & 152.7 & 144.2 & 141.7 & 127.8 \\
\hline 102 & 130.5 & 145.0 & 150.7 & 146.2 & 148.2 & 150.0 & 148.0 & 133.9 \\
\hline 174 & 132.6 & 148.1 & 153.9 & 149.3 & 151.3 & 143.9 & 142.0 & 127.8 \\
\hline 342 & 126.4 & 139.1 & 140.8 & 139.5 & 140.1 & 136.6 & 136.0 & 123.8 \\
\hline 494 & 121.6 & 132.1 & 131.0 & 131.9 & 131.5 & 130.8 & 131.2 & 120.6 \\
\hline 864 & 115.9 & 124.0 & 120.3 & 123.3 & 122.0 & 125.3 & 126.6 & 117.8 \\
\hline
\end{tabular}

$*$ Case $\mathrm{G}$ and Case $\mathrm{H}$ are derived from the results of other cases 


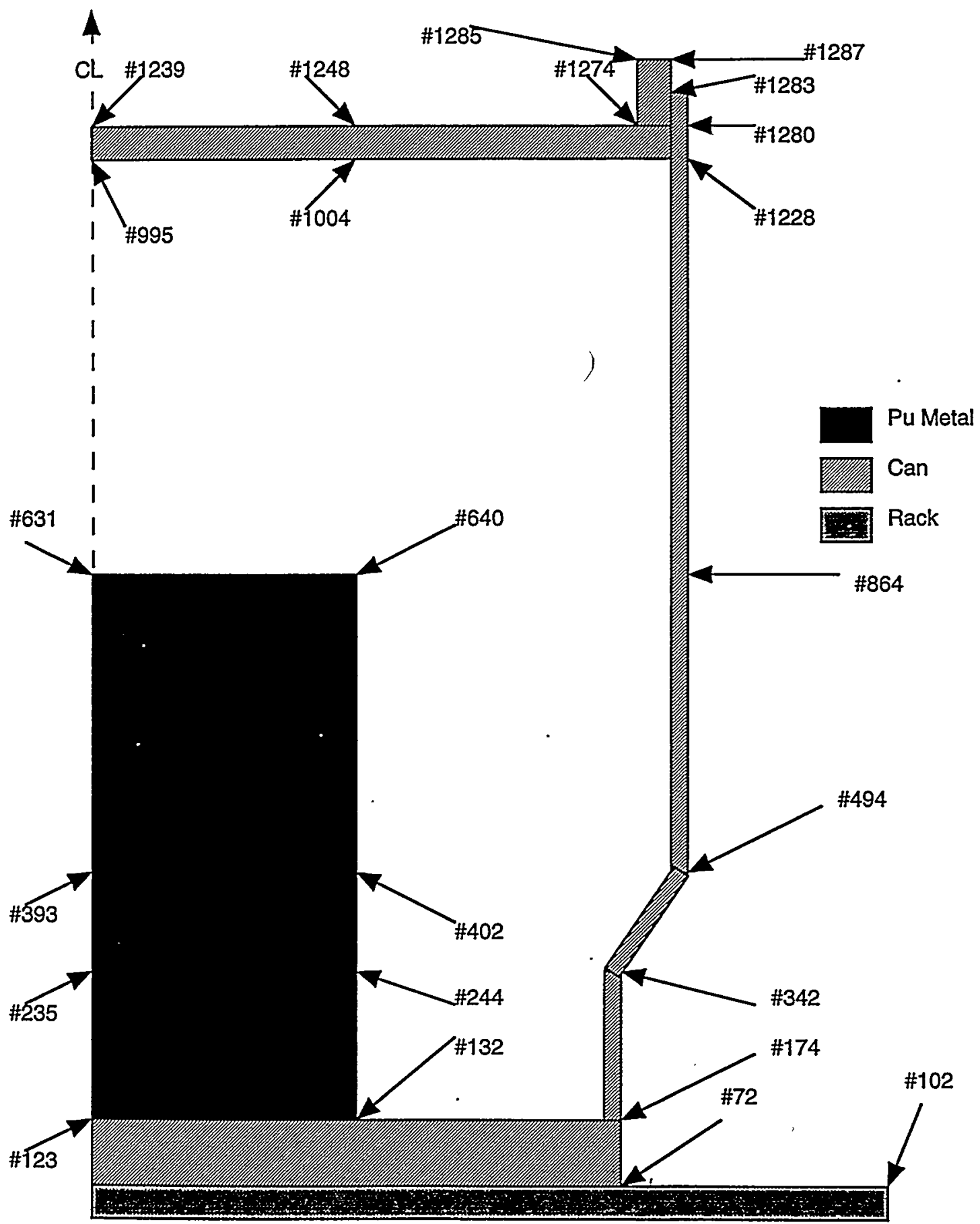

Figure 7. Node Location for Single Can Configuration 


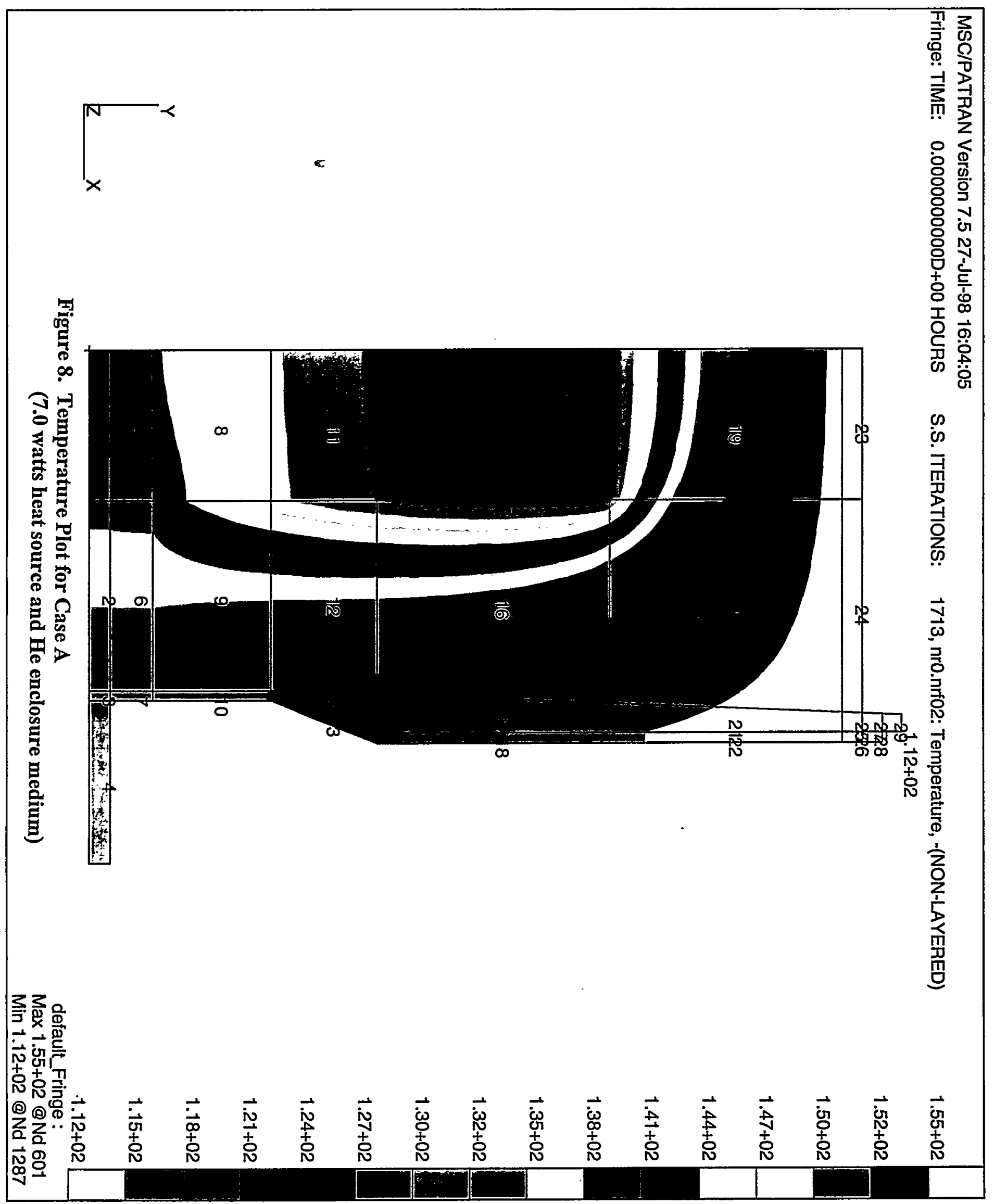




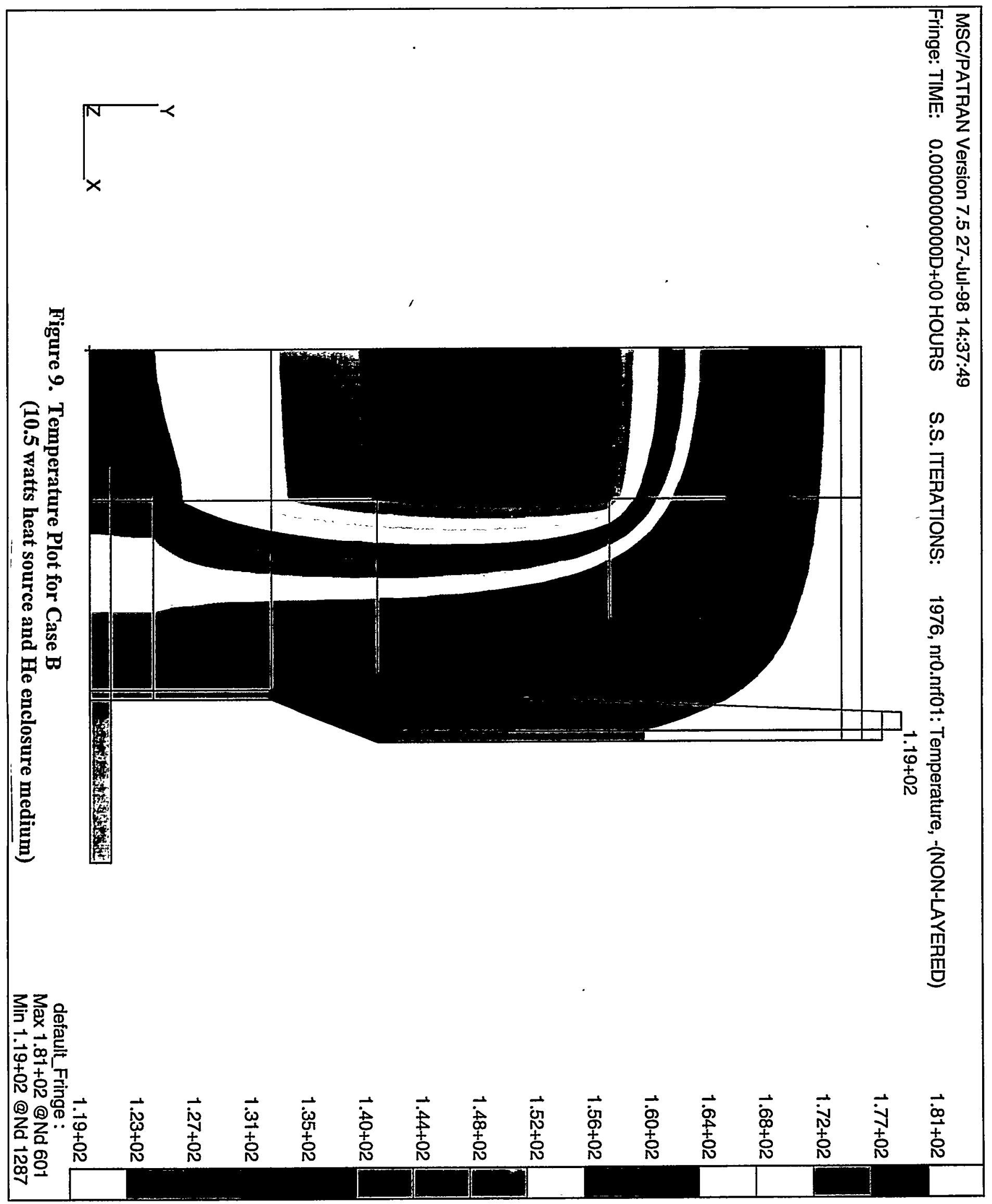




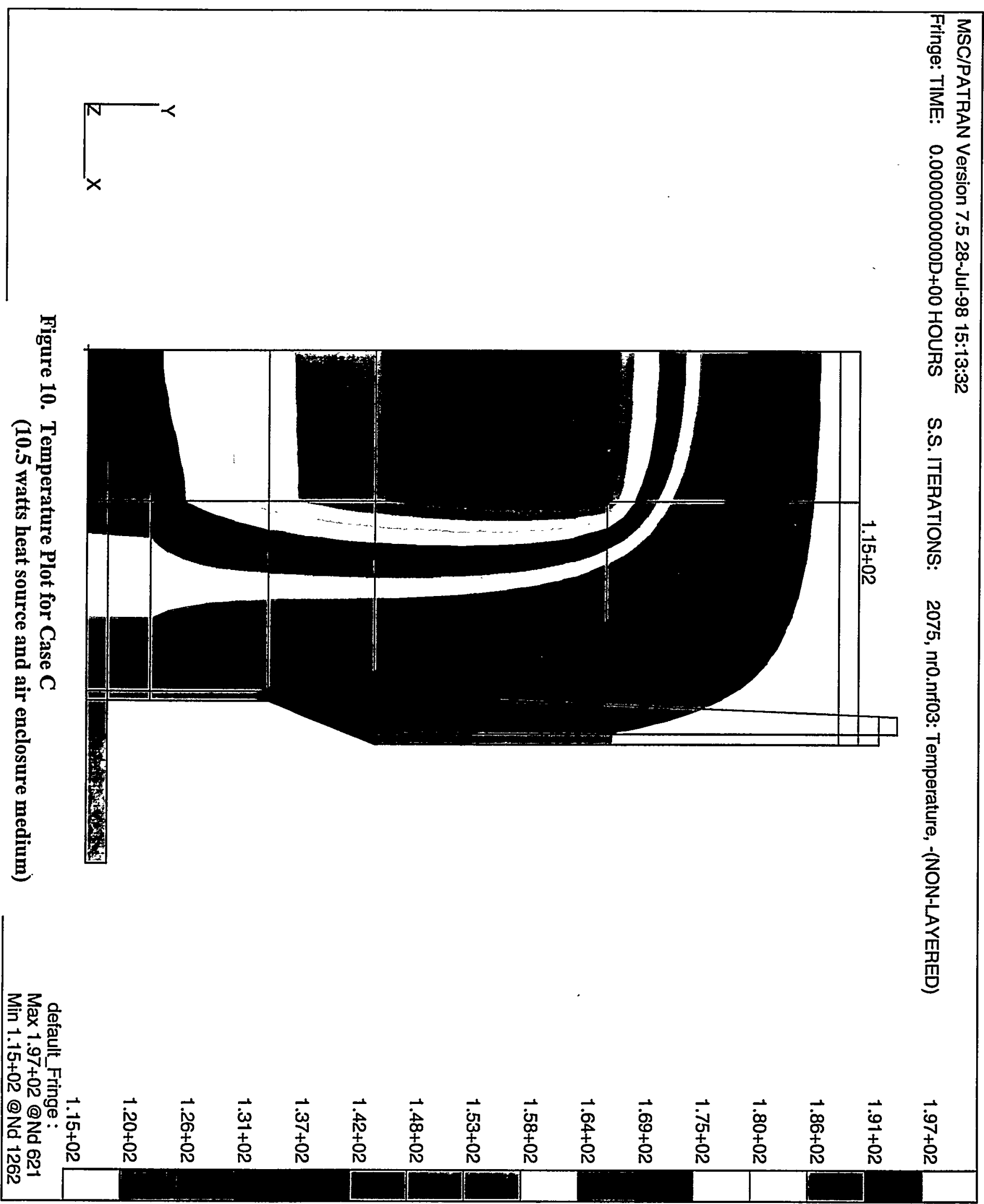




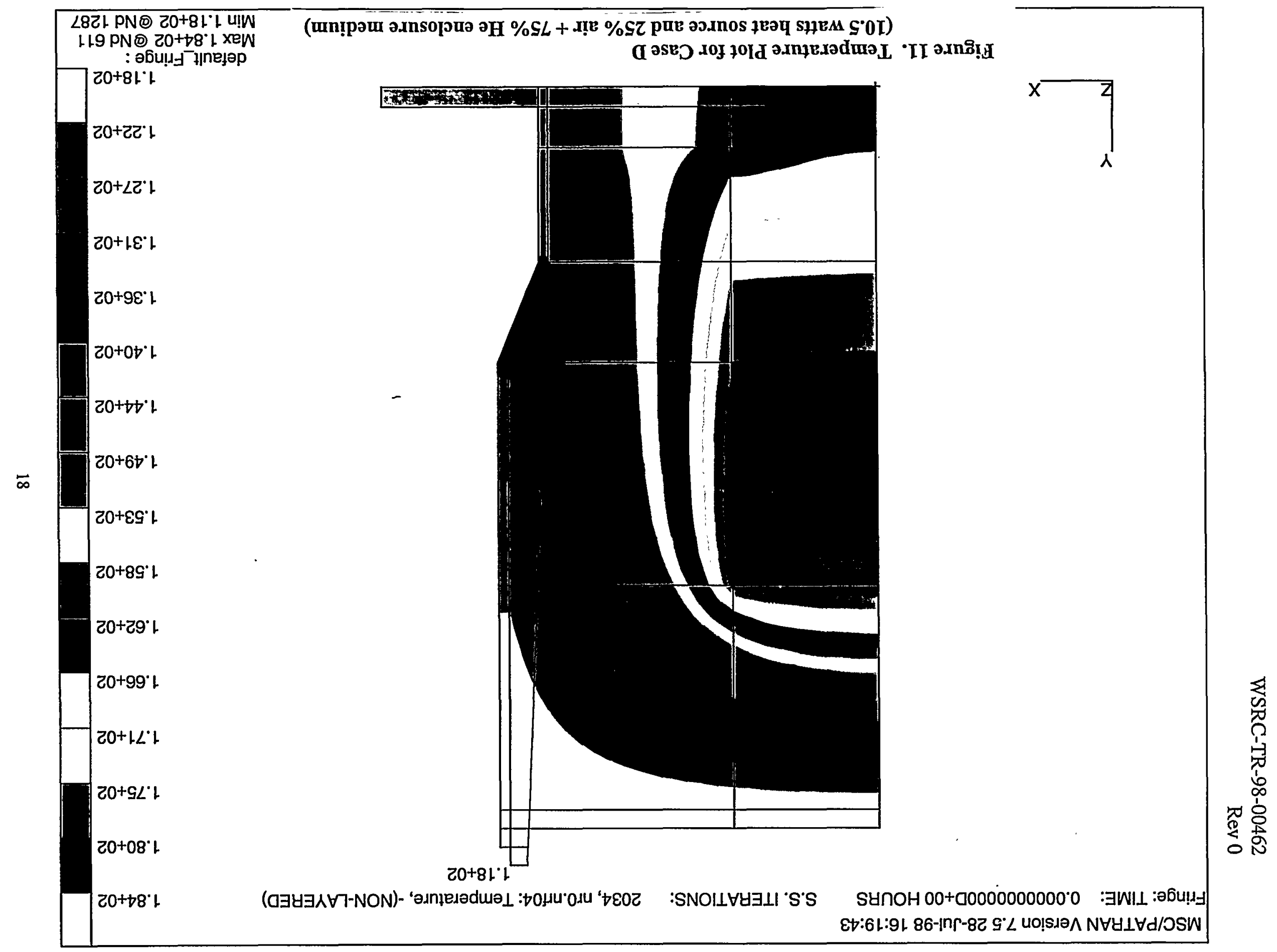




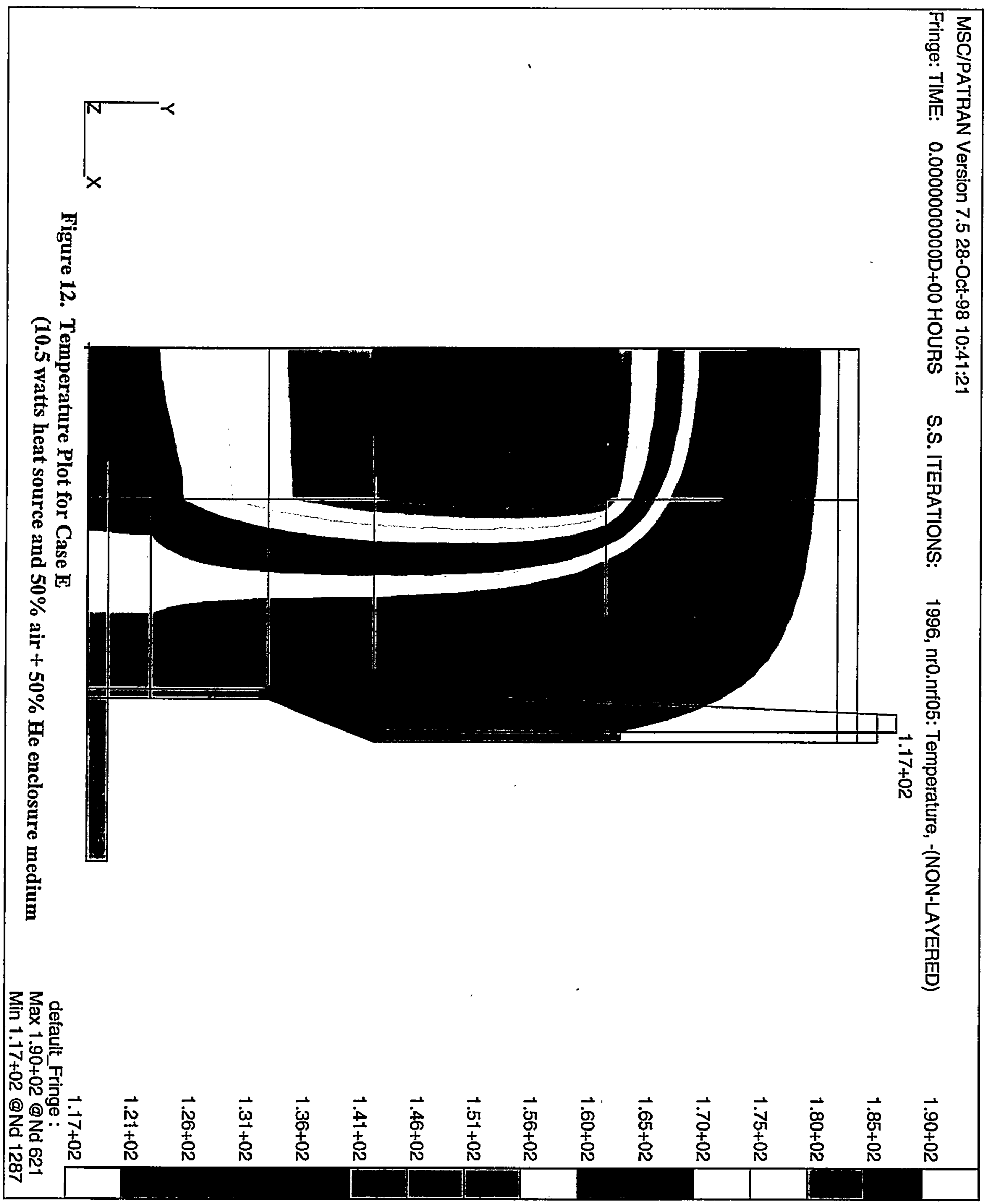


WSRC-TR-98-00462

Rev 0

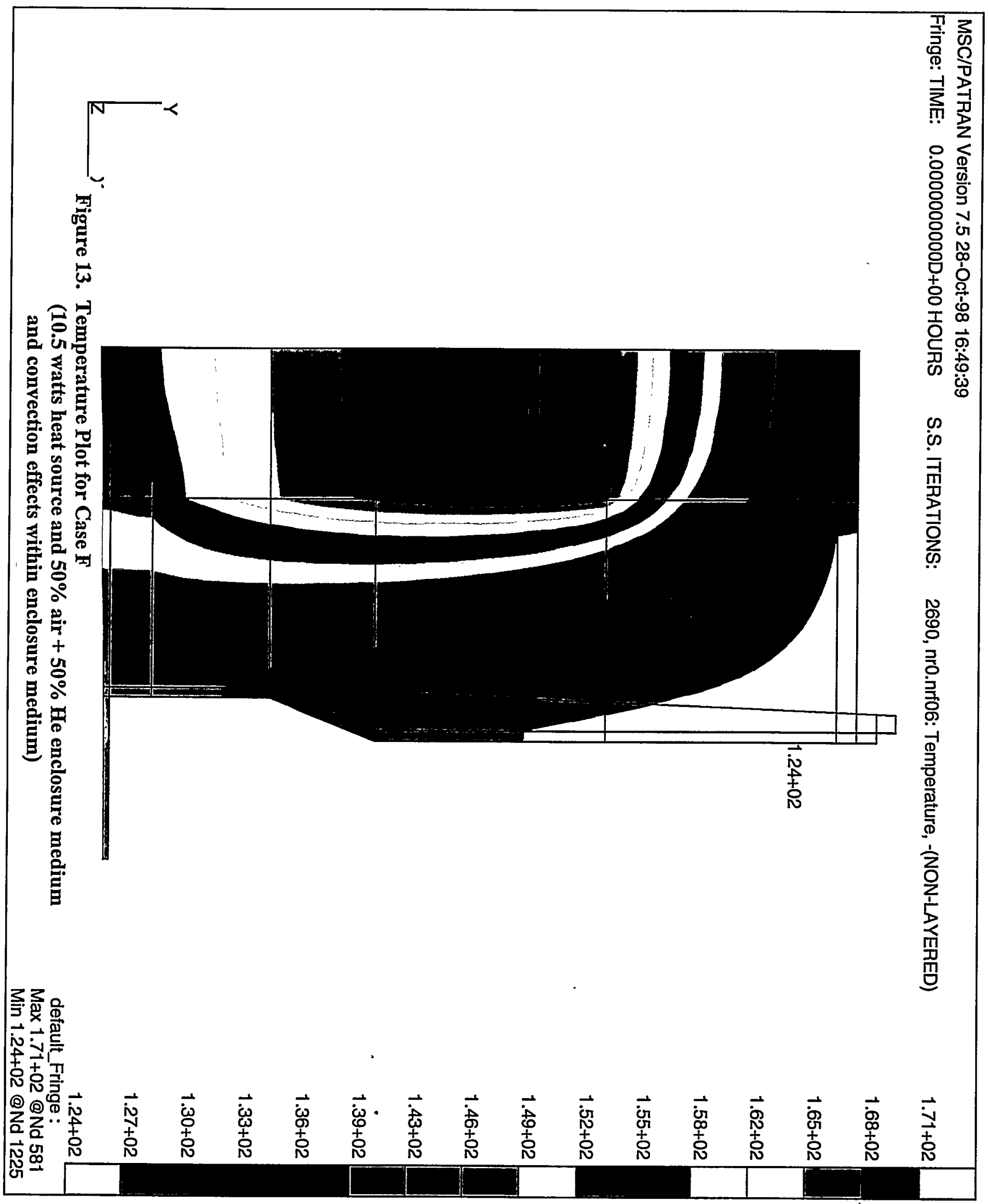


Table 5. Temperature at Different Locations for Two-Stack Can Configuration

\begin{tabular}{|c|c|c|c|c|c|c|c|}
\hline Cases & Case AA & Case BB & Case CC & Case AAA & Case BBB & Case CCC & Case DDD \\
\hline $\begin{array}{c}\text { Node\# I } \\
\text { Temp }\end{array}$ & ${ }^{\circ} \mathrm{F}$ & ${ }^{\circ} \mathrm{F}$ & ${ }^{\circ} \mathrm{F}$ & ${ }^{\circ} \mathrm{F}$ & ${ }^{\circ} \mathrm{F}$ & ${ }^{\circ} \mathrm{F}$ & ${ }^{\circ} \mathrm{F}$ \\
\hline 1 & 149.97 & 149.96 & 149.82 & N/A & N/A & N/A & N/A \\
\hline 11 & 150.15 & 150.14 & 150.00 & 159.42 & 159.42 & 159.21 & 174.06 \\
\hline 183 & 154.57 & 154.55 & 154.41 & 163.09 & 163.09 & 162.88 & 177.21 \\
\hline 725 & 178.00 & 177.98 & 177.85 & 185.10 & 185.10 & 184.91 & 197.10 \\
\hline 1103 & 160.29 & 160.27 & 159.98 & 162.91 & 162.91 & 162.60 & 167.42 \\
\hline 1385 & 161.73 & 161.71 & 161.43 & 164.33 & 164.33 & 164.02 & 168.80 \\
\hline 2040 & 180.82 & 180.79 & 180.54 & 183.10 & 183.10 & 182.82 & 187.02 \\
\hline 2736 & 124.66 & 124.63 & 124.02 & 125.99 & 125.98 & 125.32 & 128.26 \\
\hline 2836 & 119.52 & 119.50 & 119.88 & 120.64 & 120.63 & 121.02 & 122.53 \\
\hline 2916 & 119.46 & 119.43 & 119.80 & 120.57 & 120.56 & 120.93 & 122.46 \\
\hline 192 & 150.79 & 150.78 & 150.63 & 159.19 & 159.19 & 158.98 & 173.37 \\
\hline 734 & 177.32 & 177.31 & 177.18 & 184.37 & 184.37 & 184.18 & 196.30 \\
\hline 1394 & 156.74 & 156.72 & 156.43 & 159.38 & 159.38 & 159.06 & 163.91 \\
\hline 2049 & 179.86 & 179.84 & 179.59 & 182.14 & 182.13 & 181.86 & 186.05 \\
\hline 3005 & 120.38 & 120.52 & 120.36 & 121.54 & 121.54 & 121.69 & 123.52 \\
\hline 1384 & .138 .85 & 138.83 & 138.87 & 141.52 & 141.52 & 141.54 & 146.12 \\
\hline 54 & 140.52 & 140.51 & 140.43 & 148.69 & 148.69 & 148.57 & 162.18 \\
\hline 59 & 138.90 & 138.89 & 138.82 & N/A & N/A. & N/A & N/A \\
\hline
\end{tabular}




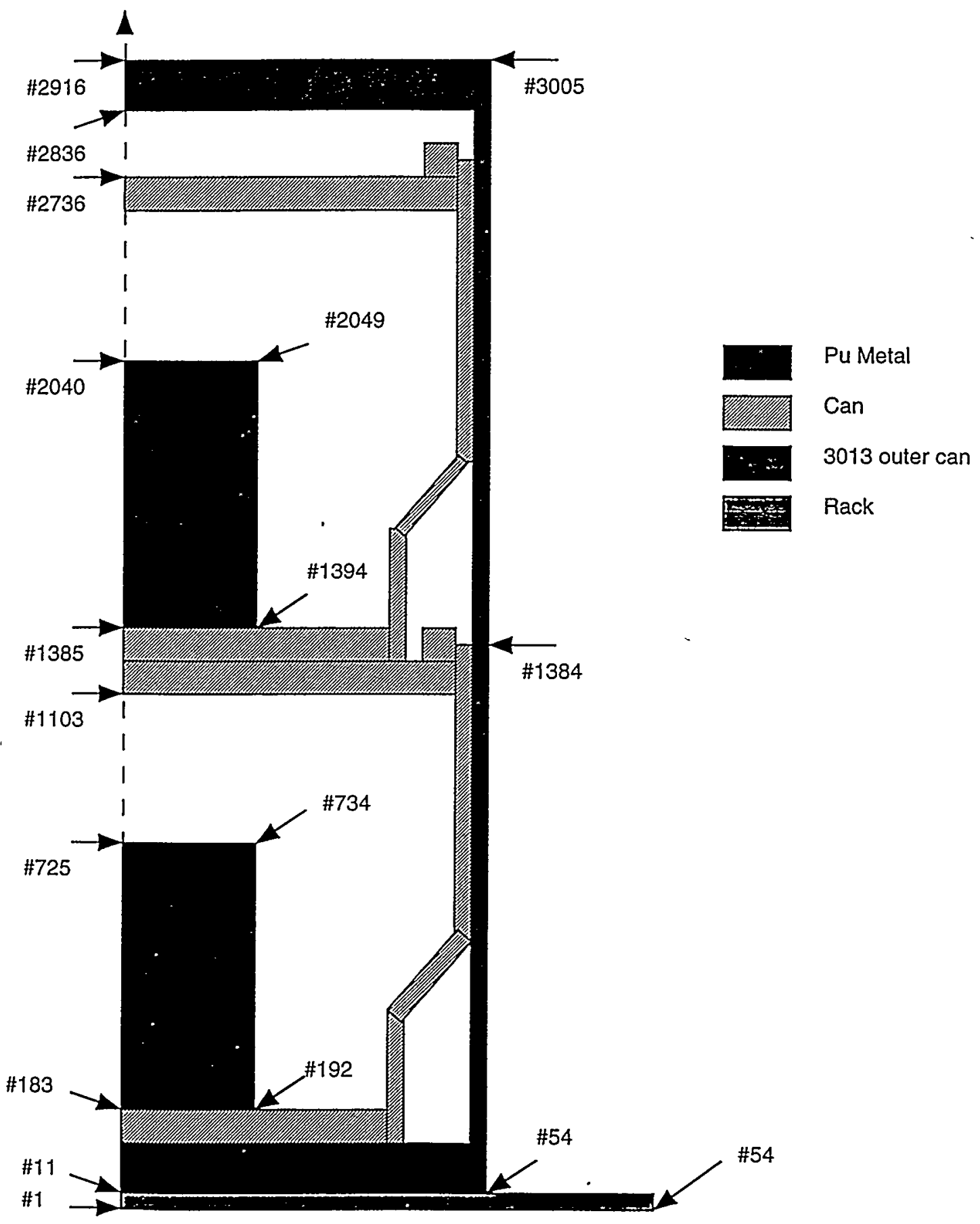

Figure 14. Node Locations for Two-Stack Can Configuration 
Rev 0

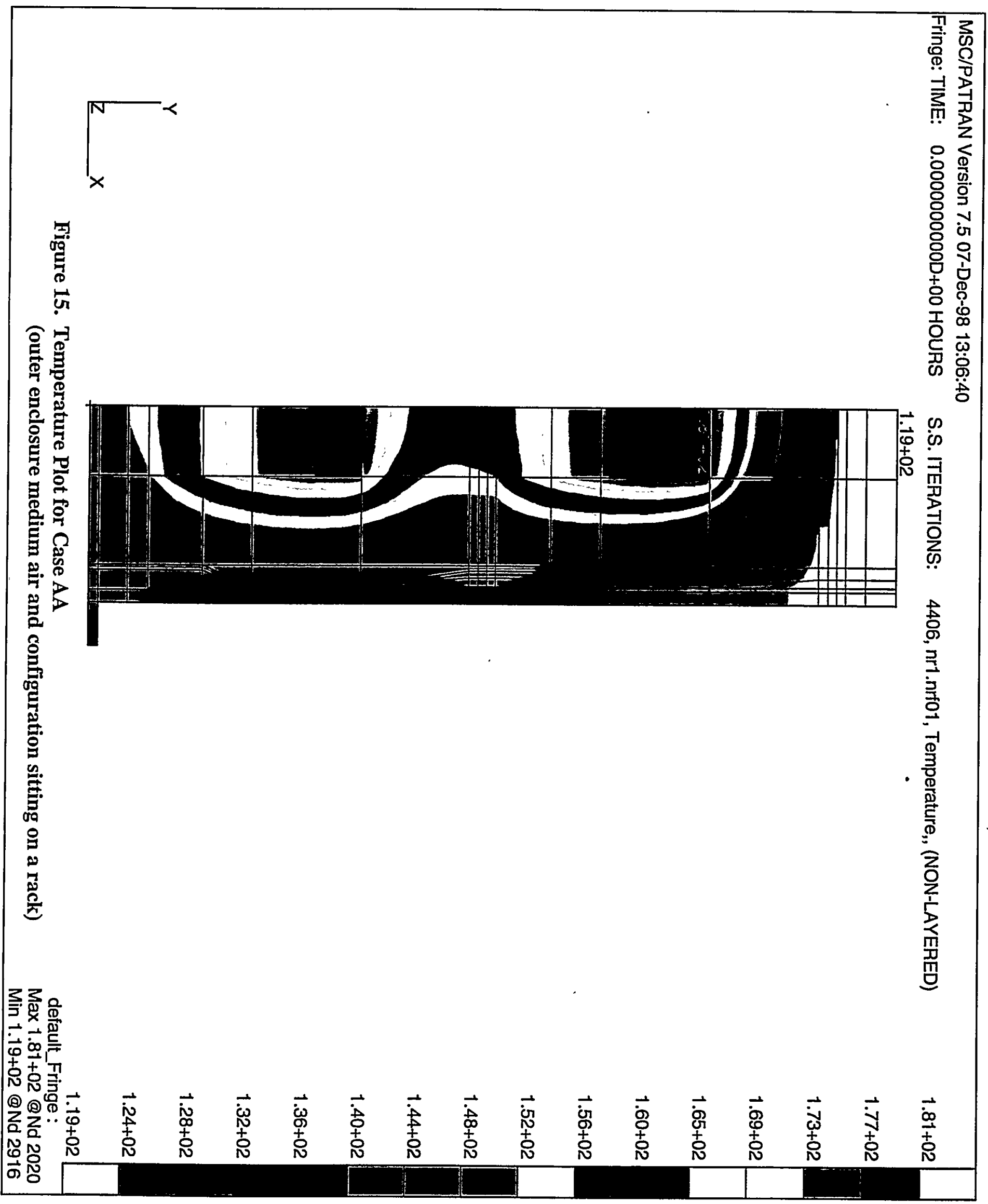




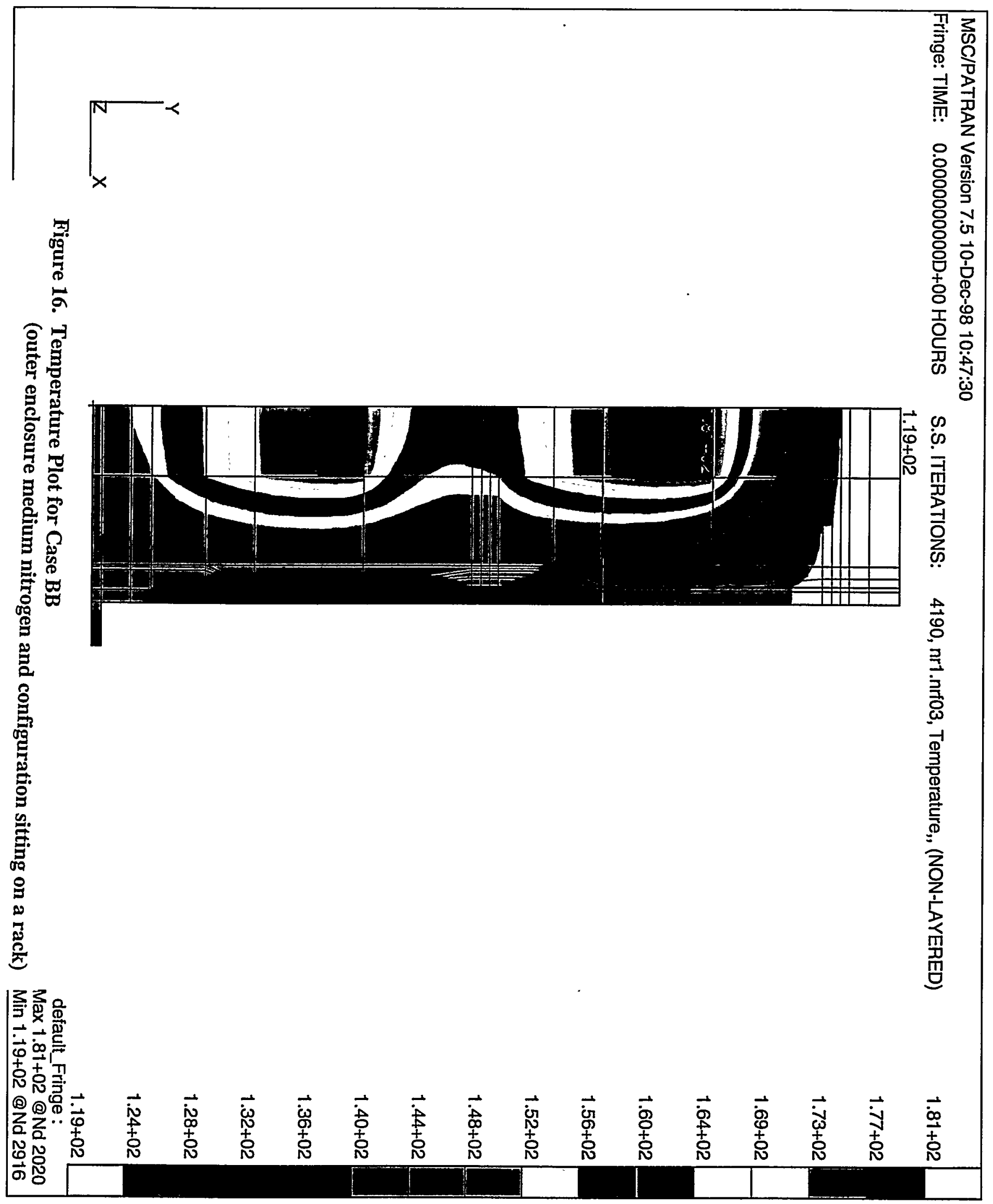


Rev 0

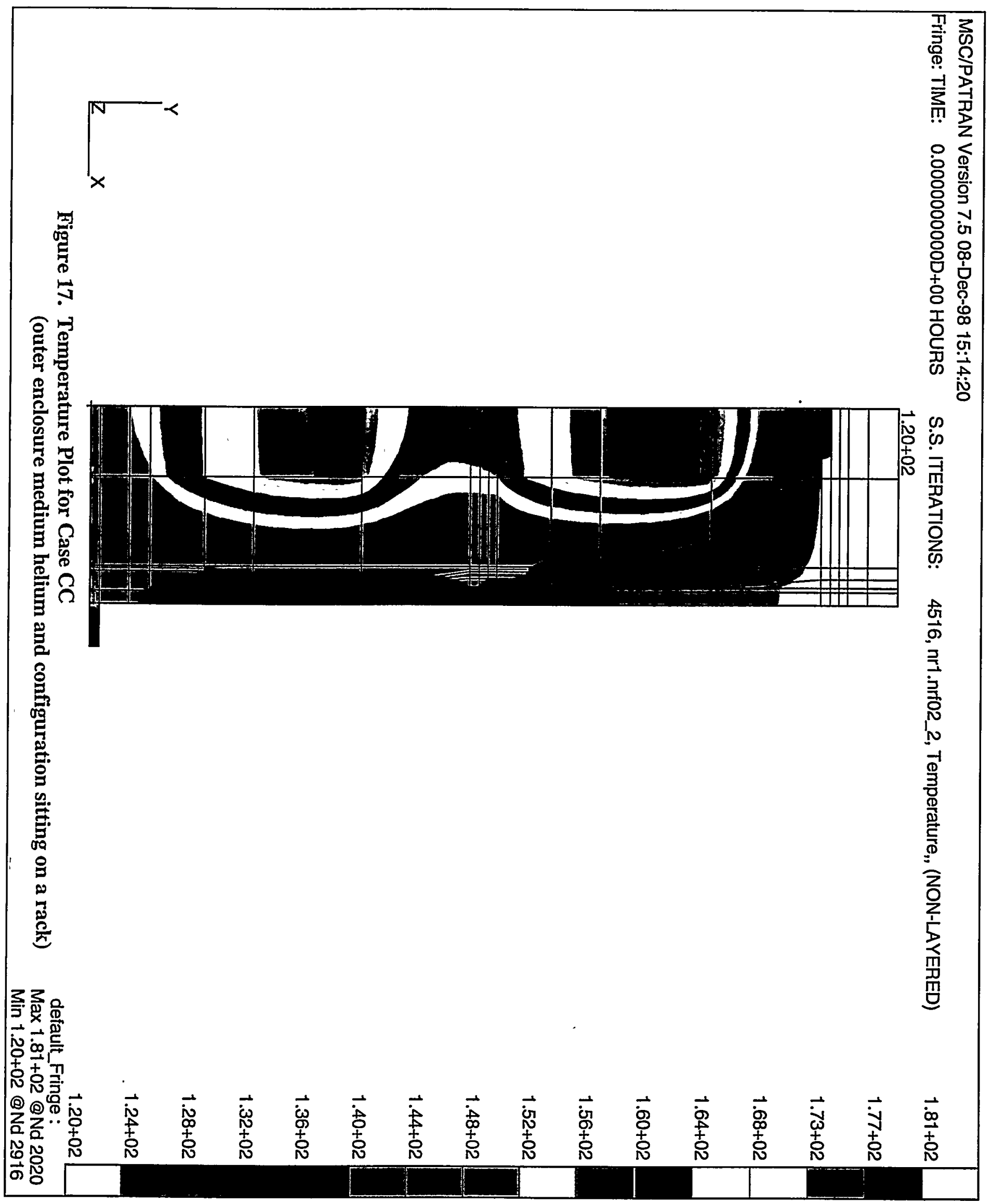




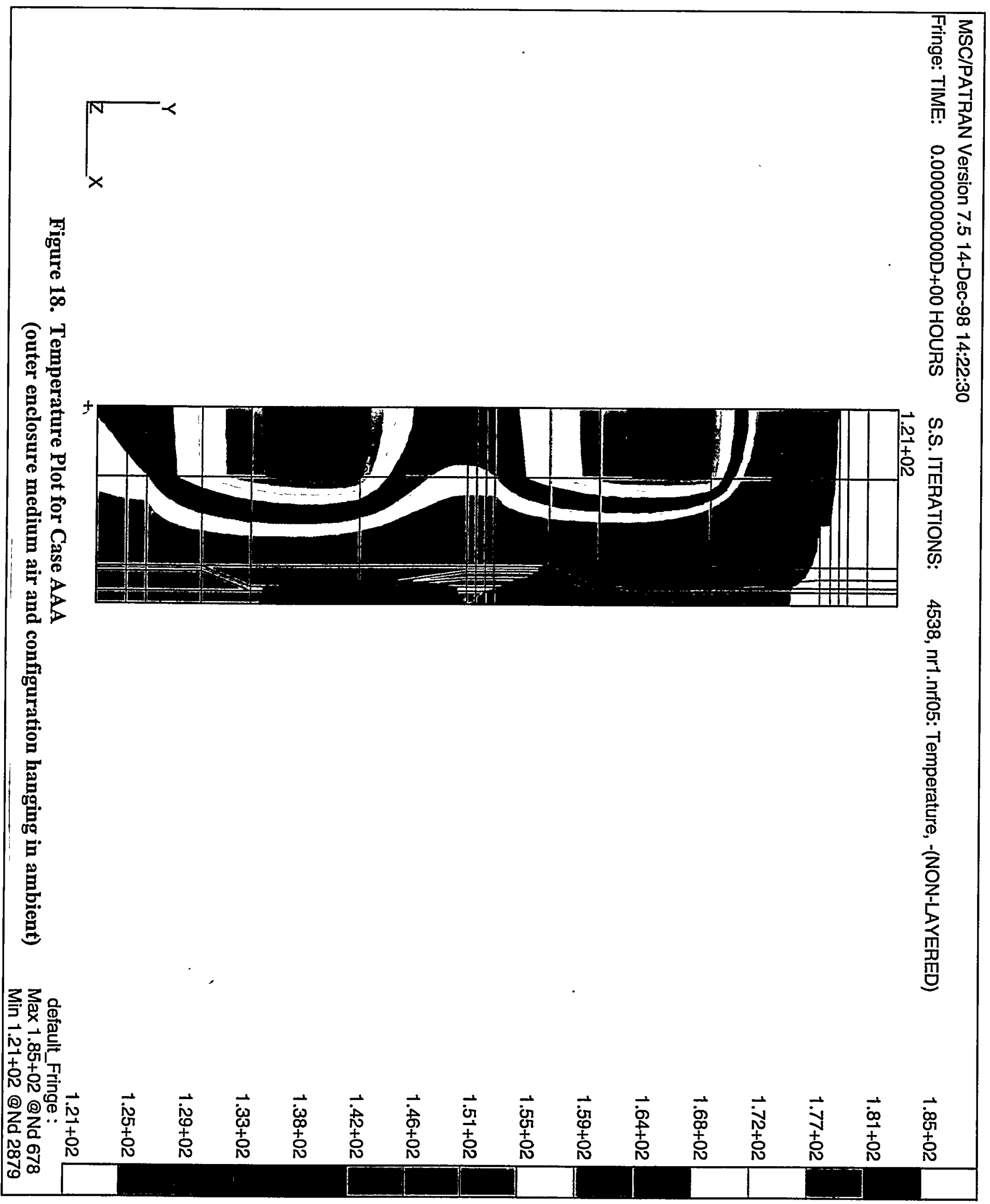


Rev 0

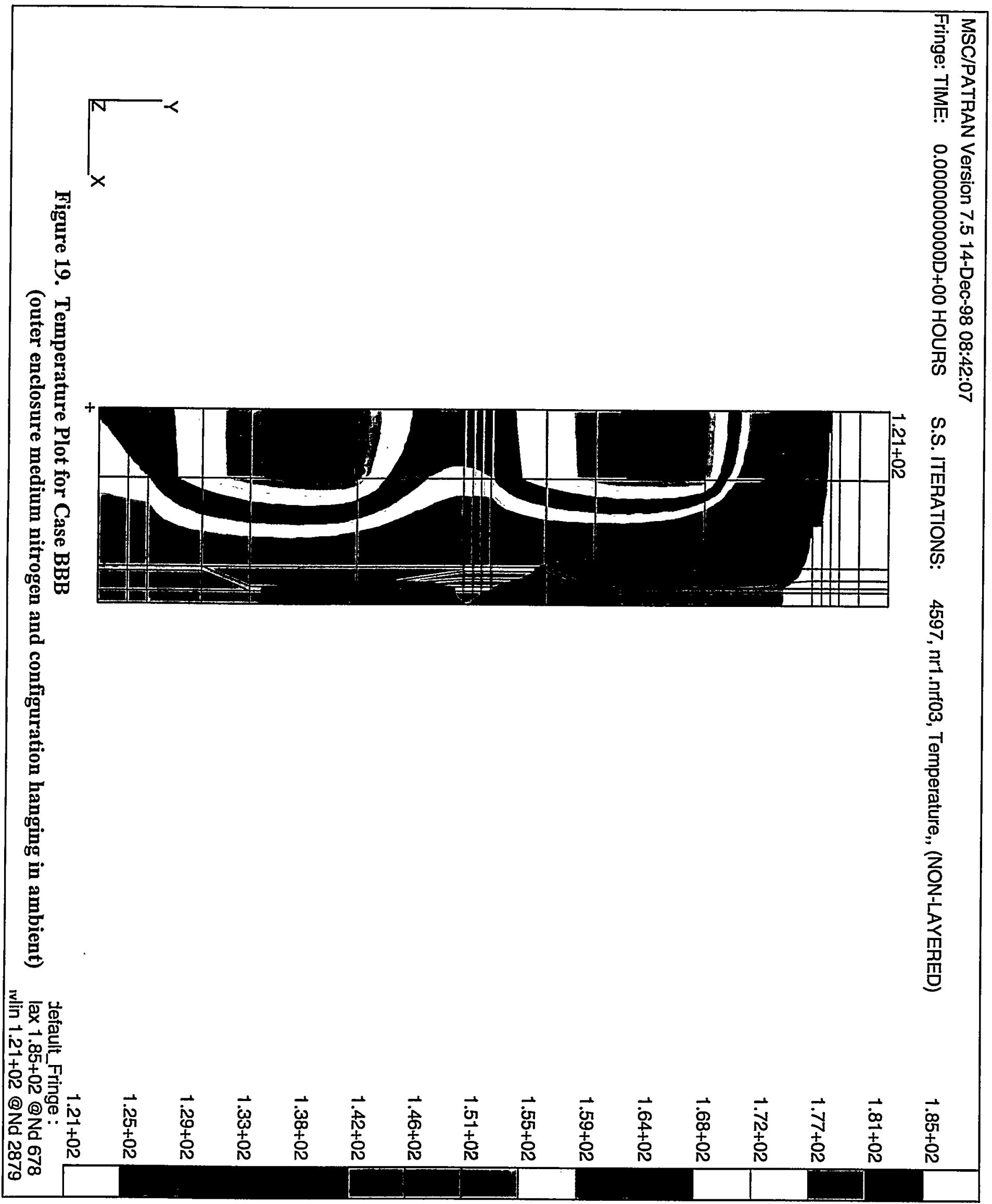




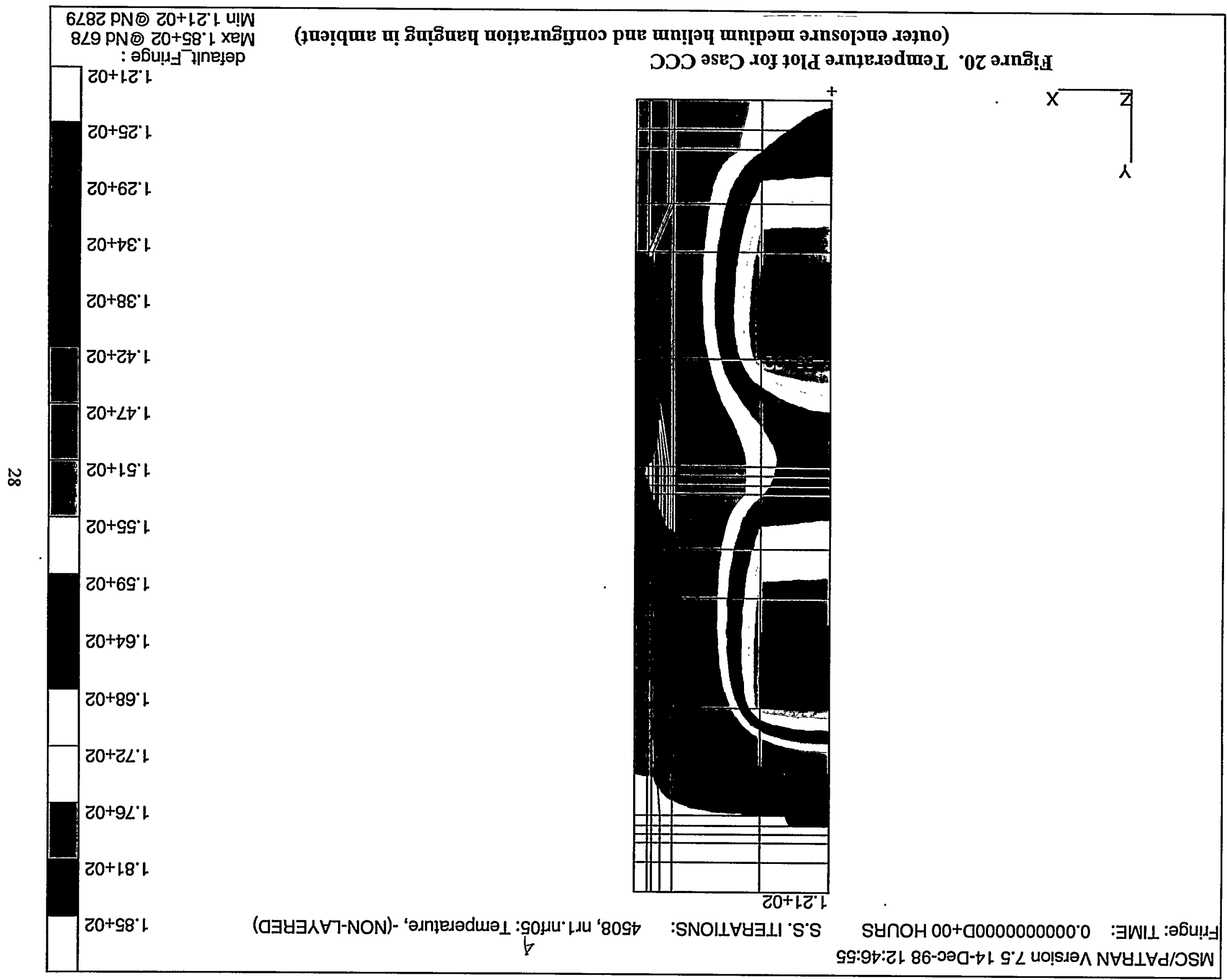

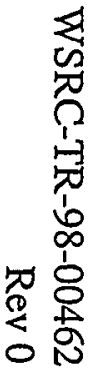


WSRC-TR-98-00462

Rev 0

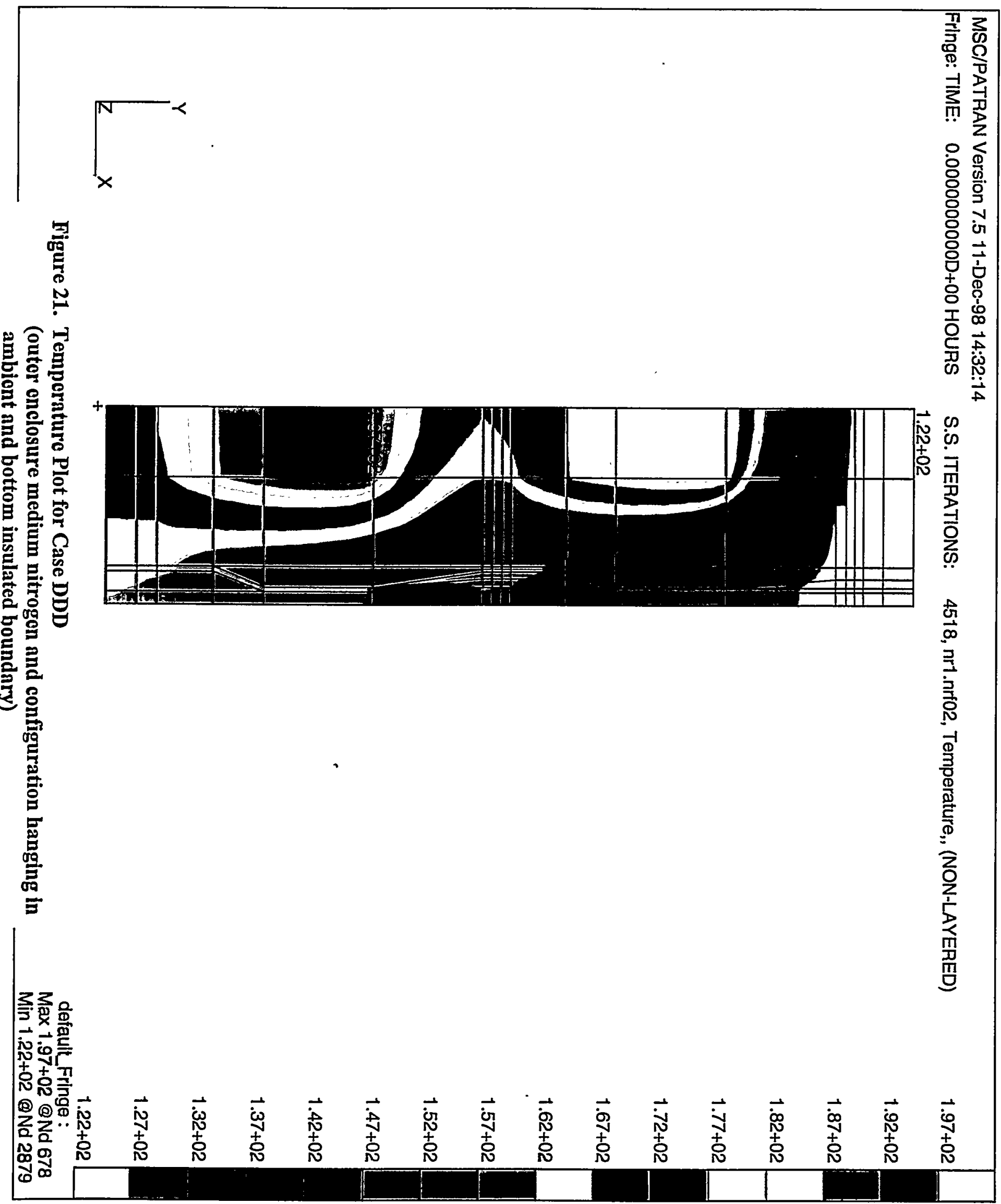




\section{References}

1. Conduct of Engineering Manual, E7, Westinghouse Savannah River Co., 1998.

2. Hensel, S. J., "Dedication Package for P3/Thermal (U)," SRT-EMS-950007, 1995.

3. MSC/PATRAN, MacNeal-Schwendler Corporation, Los Angeles, CA 90041.

4. MSC/Thermal, MacNeal-Schwendler Corporation, Los Angeles, CA 90041.

5. Hensel, S. J. and Lee, S. Y., "Thermal Analysis of Storage Cans (U)," WSRCTR-96-0078, 1996. 